\title{
Os Espaços Livres Residenciais Na Cidade de São Paulo
}

\author{
Brutus Abel Fratuci Pimentel
}

Brutus Abel Fratuci Pimentel

Pesquisador Fapesp

Bolsa Iniciação Cientifica

$1996 / 1997$

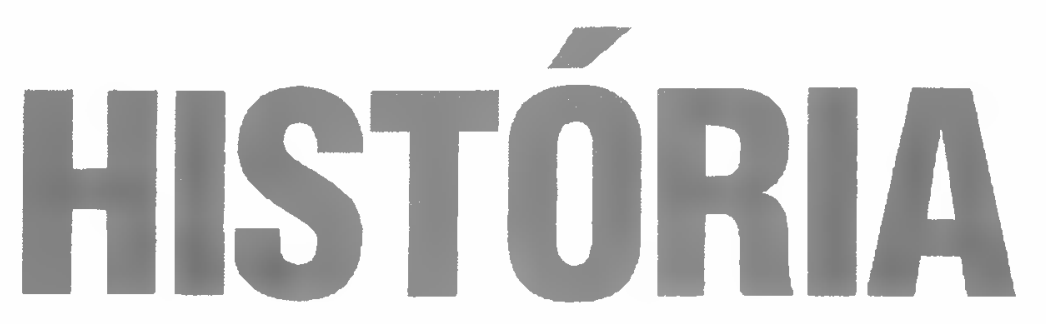


Os espaços livres possuem um aspecto bastante singular com respeito ao paisagismo

residencial. Este texto é um estudo das linhas projetuais nas áreas não edificadas e das diversas formas de implantação da residência paulistana. Sob uma perspectiva histórica procuramos discursar sobre o desenvolvimento projetual que as áreas livres residenciais particulares assumiram neste século.

The opened spaces have a quite uncommon aspect when related to the residential landscape. This text is an essay about the opened areas projectual lines and the several paulistana house site plans forms. Under a historical point of view it has discussed the projectual development of the particular open areas acquired in this century. 


\section{Os Espaços Livres Residenciais Na Cidade de São Paulo}

$\mathrm{O}$

s projetos paisagísticos nas áreas livres das residências paulistanas não devem ser vistos como um estudo separado da própria residência enquanto objeto construído. A condiçāo básica para a existência de tais projetos é a própria disponibilidade de área livre no lote urbano, que surgiu na cidade de São Paulo somente no fim do século passado. Posteriormente, o que se apresentava de forma genérica na cidade eram edificaçōes agrupadas umas ao lado das outras, sem recuos frontais ou laterais. Portanto, o estudo do tratamento das áreas livres, no limite do lote, inicia-se com o aparecimento de tais recuos e, concomitantemente, por uma transformação social da ordem estabelecida na vida cotidiana das moradias particulares.

Historicamente a casa paulistana, na conglomeração urbana existente em meados do século 19, nada mais era do que um pequeno vilarejo de fortes relações com os desenhos urbanos portugueses, estrutura esta de claro traço medieval. Eram residências pobres sem grandes ornamentos e/ou preocupações estilísticas, construídas sobre os limites do lote, deixando somente aos fundos um pequeno quintal sem grande tratamento planejado. Desse período o que se destacam são as chácaras rurais localizadas no interior da cidade. Pertencentes às famílias mais abastadas da sociedade paulistana, tais casarões eram como pequenas fazendas, possuindo infra-estrutura própria e quase auto-suficiente. A importância destas chácaras era tal que na metade do século 19 podiase constatar a existência de um verdadeiro cinturão destas construções no entorno imediato da cidade. Totalmente rurais, detinham o peso mais significativo da economia extremamente agrícola deste período.

Esta condição "urbana" atrasada até para os padrões de algumas cidades brasileiras da época, manteve-se até por volta da década 1870 ,

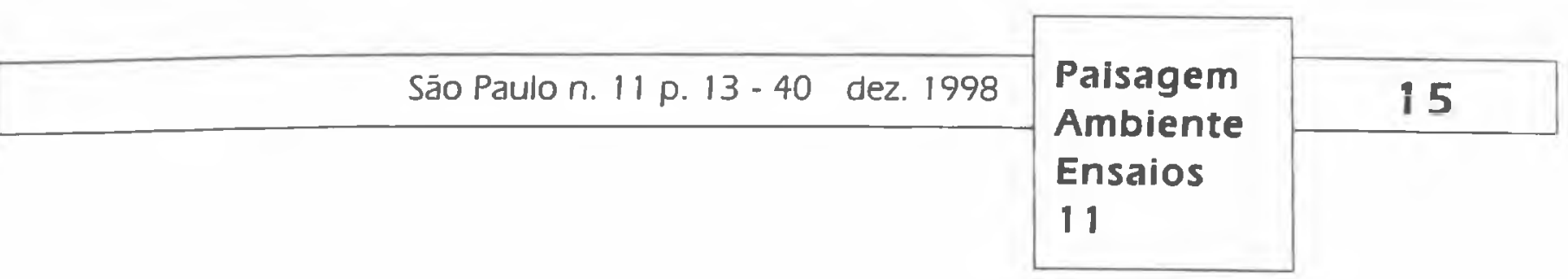


Fratuci

\section{Pimentel}
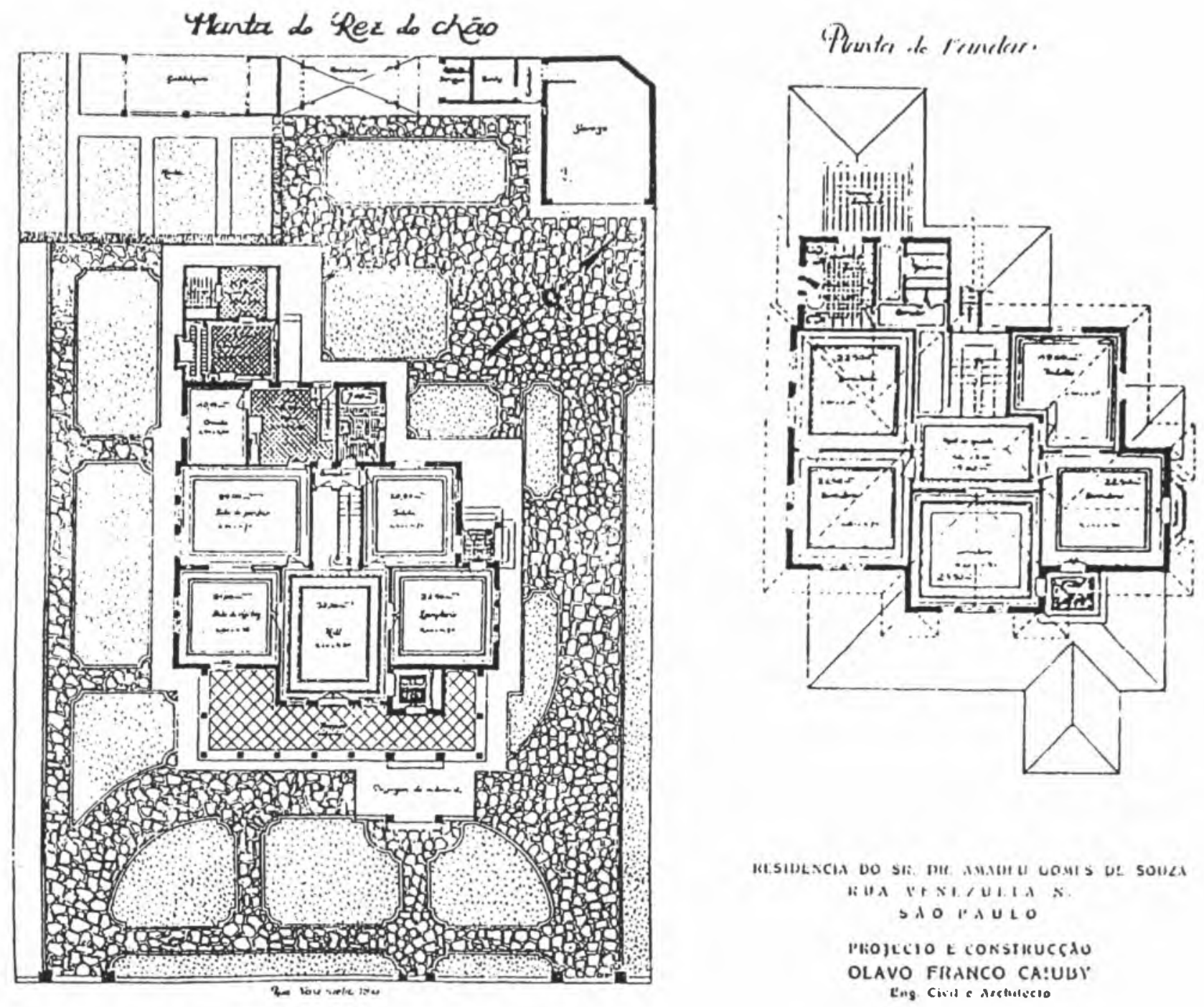

Figura 1: Residência eclética Amadeus Guimaräes de Sousa - projeto de Olavo Franco Cauby. Tipica planta de casa eclética do início do século

Fonte: Álbum arquitetura e construçāo de Luiz Muniz

quando temos a substituição da cultura da cana-de-açúcar pela do café, dando início a entrada de novos capitais para a cidade. Junto a essa "viravolta" econômica, a abolição da escravatura possibilitou a vinda de imigrantes europeus a São Paulo para o trabalho nas lavouras de café, em vez dos negros que outrora cortavam a cana. Os imigrantes, principalmente italianos, foram os grandes "agentes modificadores" da casa particular paulistana e da estrutura da vida cotidiana familiar através de novos costumes e hábitos que levaram, gradativamente, a uma redução das áreas de serviço e da cozinha; concomitantemente surge uma maior preocupação com a higiene oriunda das concepções vindas do Velho Mundo. O sanitarismo literalmente entra em "moda" As casas, portanto, começam a ser (re)desenhadas de forma a possuirem recuos laterais para uma maior insolação e salubridade. Em 1911 o Código do 
Serviço Sanitário da prefeitura começa a exigir, então legalmente, afastamento da edificação com relação aos limites do lote. Há a constatação empírica de que o programa da casa rural tornara-se obsoleto em confronto com a nova gama de necessidades originárias desta nova "europeização"

As características provincianas de São Paulo lentamente desaparecem, deixando margens para um novo desenvolvimento urbano; a expansão da cidade acelera-se no final deste século esbarrando nas antigas chácaras periféricas. A população aumenta e as grandes chácaras rurais têm seus terrenos loteados, dando lugar aos casarões urbanos: ao palacete paulistano, e este torna-se cronologicamente a primeira residência urbana a ter tratamento paisagístico projetado. É o período do ecletismo, no qual grandes residências de desenho europeu são erguidas.

Adequando-se a qualquer modismo estilístico, os casarões do início do século 20 apresentavam uma forte relação de representação de status da classe mais rica; o fachadismo e o tratamento dos grandes jardins frontais como "troféus" de elegância e bom gosto eram a característica arquitetônica maior da elite cafeeira: simbólicos, ou seja, carregavam a vontade de uma expressão monumental definida no ecletismo burguês. Os jardins nasciam mais como um valor imagético do que de conforto ou bem-estar social ${ }^{1}$ Como um emblema definiam, juntamente com o estilo e a suntuosidade da casa, a sofisticação da família.

Destacamos, portanto, genericamente os seguintes pontos a respeito das áreas livres e dos casarões paulistanos:

1 - Com enormes jardins de estilos franceses ou ingleses, as residências possuíam tratamento paisagístico emoldurando a edificação através de um traçado rigoroso. Sua intenção era de "valorização" da edificação;

2 - O principal e maior jardim sempre localizava-se à frente da moradia, formando um quadro estilístico à fachada da casa;

(1) A utilização do jardim eclético pelas famílias mais abastadas da sociedade dava-se também freqüentemente na forma de lazer (como leituras e recitais), porém o que se leva em conta neste estudo é a condição que o jardim possuía perante toda a sociedade. É mais importante, neste caso, sua relevância à totalidade da cidade do que a particularização da utilidade familiar. Desta forma, quando se diz que os jardins ecléticos possuíam mais valor simbólico do que de lazer institucionalizado, refere-se estritamente ao ponto de vista de sua linguagem urbana.

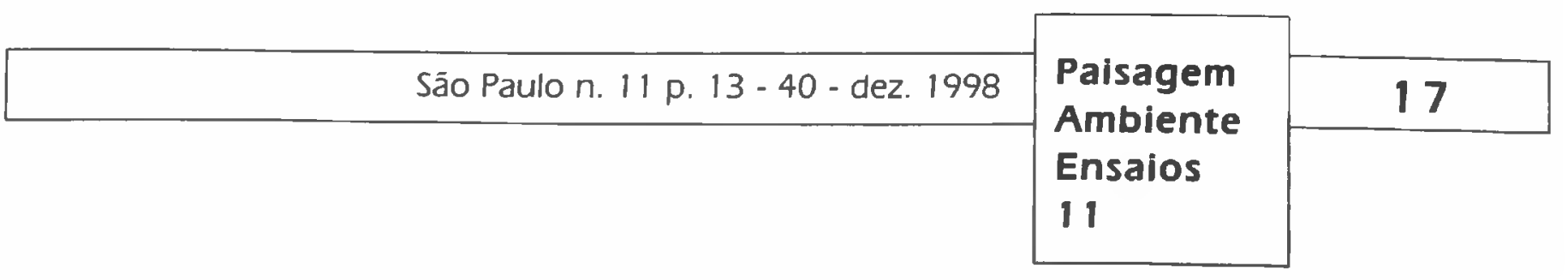




\section{Brutus \\ Abel \\ Os Espaços Livres Residenciais na \\ Cidade de São Paulo}

Fratuci

Pimentel

$$
\begin{aligned}
& \text { Pogiecto do Fondars } \\
& \text { do Rtand }
\end{aligned}
$$

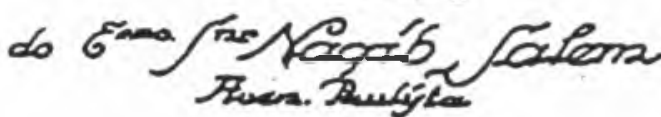

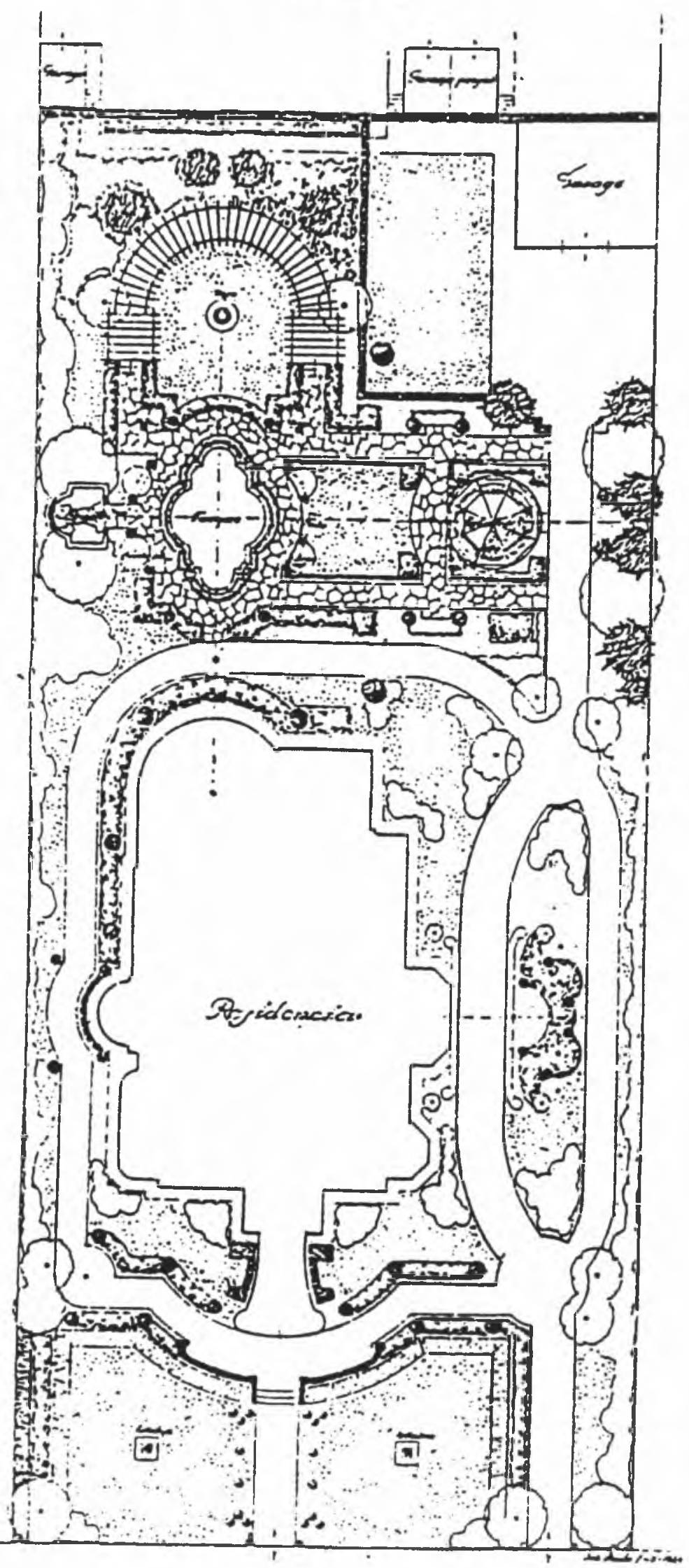

$$
\text { ZEm Pantion }
$$

Figura 2: Residência do Sr. Nagib Salem. 0 desenho é o projeto do jardim da casa em estilo neocolonial

Fonte: Álbum arquitetura e construção de Luiz Muniz 
3 - As áreas de senviços eram sempre "desvalorizadas" pelo valor de hierarquia social apropriada fisicamente. Localizavam-se quase sempre nos fundos do lote, onde estavam lado a lado com os indícios de uma época rural como: pomares, hortas, galinheiros e passeios para crianças, estes também escondidos dos transeuntes e visitas;

4 - Há a supervalorização da cultura européia, principalmente a francesa, tanto na linguagem, modo e estilo de vida dos moradores, como na presença de esculturas e ornamentos, e na qualidade de plantas européias escolhidas nos jardins, em sua maioria importadas juntamente com o projeto paisagístico;

5 - Presença de uma estética classicizante, característica imposta pelo estilo eclético.

Um grande marco para o desenvolvimento do paisagismo particular paulistano deste período foi a implantação de grandes bairros-jardins, que delimitaram significativas áreas verdes de uso restrito e particular, distanciando-se dos bairros de formação popular. O primeiro grande bairro-jardim foi o Jardim América, fruto de um empreendimento imobiliário da Cia. City, em 1910. Após ele, outros bairros foram erguidos como o Alto da Lapa, Pacaembú, Cidade Jardim, Jardim Europa, Morumbi e Alto de Pinheiros. Atualmente, tais bairros são os de maior padrão aquisitivo da cidade.

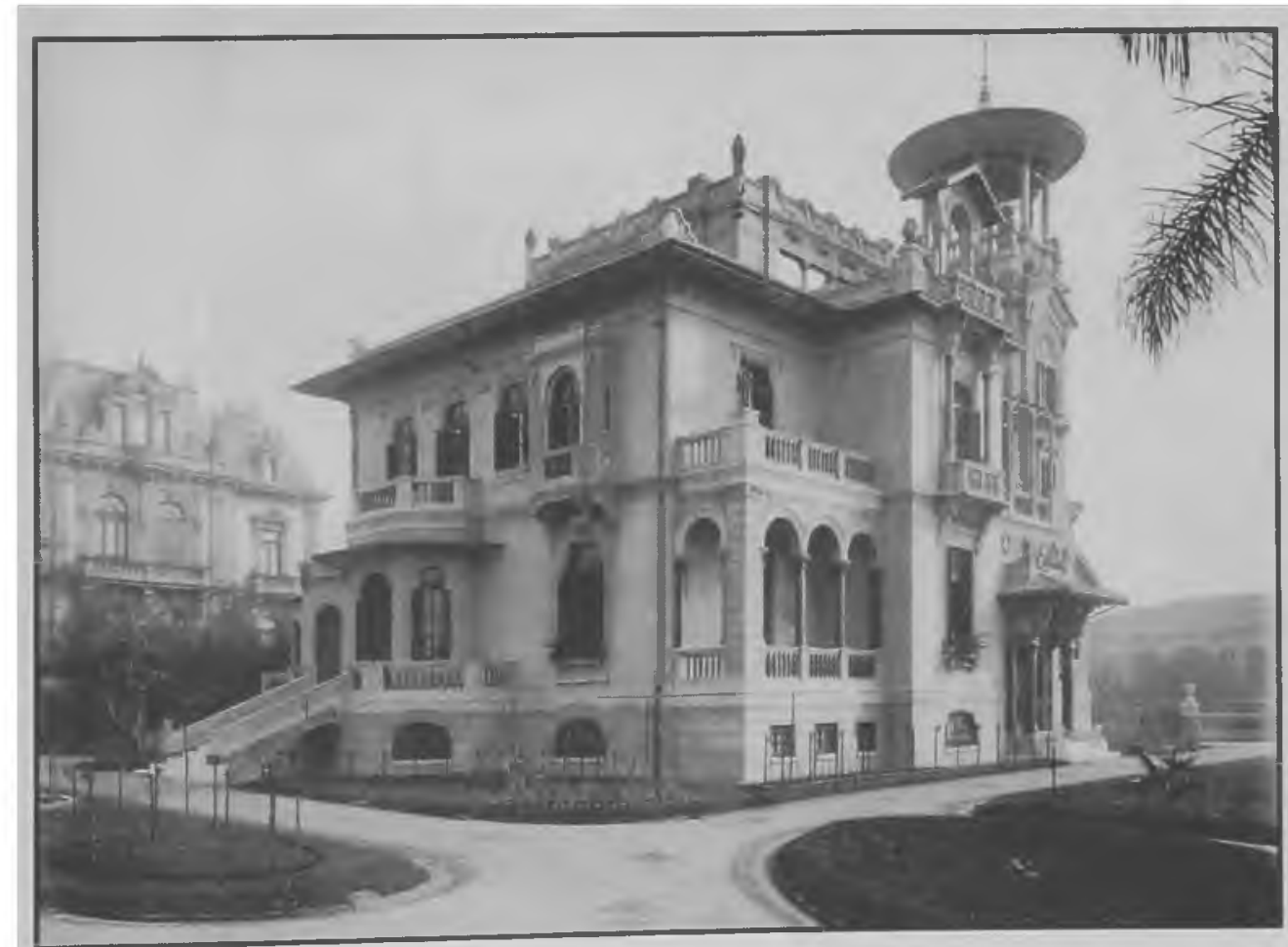

Figura 3: Residência Lupércio T. de Camargo. Este palacete do início do século foi uma das mais representativas construçóes particulares do estilo eclético. Nele podemos observar expressivas características de um casarāo: sua implantação central, seus ornamentos /mesclas de estilos clássicos), a volumetria que remete a uma construção medieval, os jardins emoldurando toda a construção, enfim, todo um conglomerado de valores estéticos que dominaram até a metade deste século e que, em muitos casos, perduram até hoje Fonte: Arquivo FAUUSP 


\section{Brutus Os Espaços Livres Residenciais na \\ Abel \\ Cidade de São Paulo}

Fratucl Pimentel

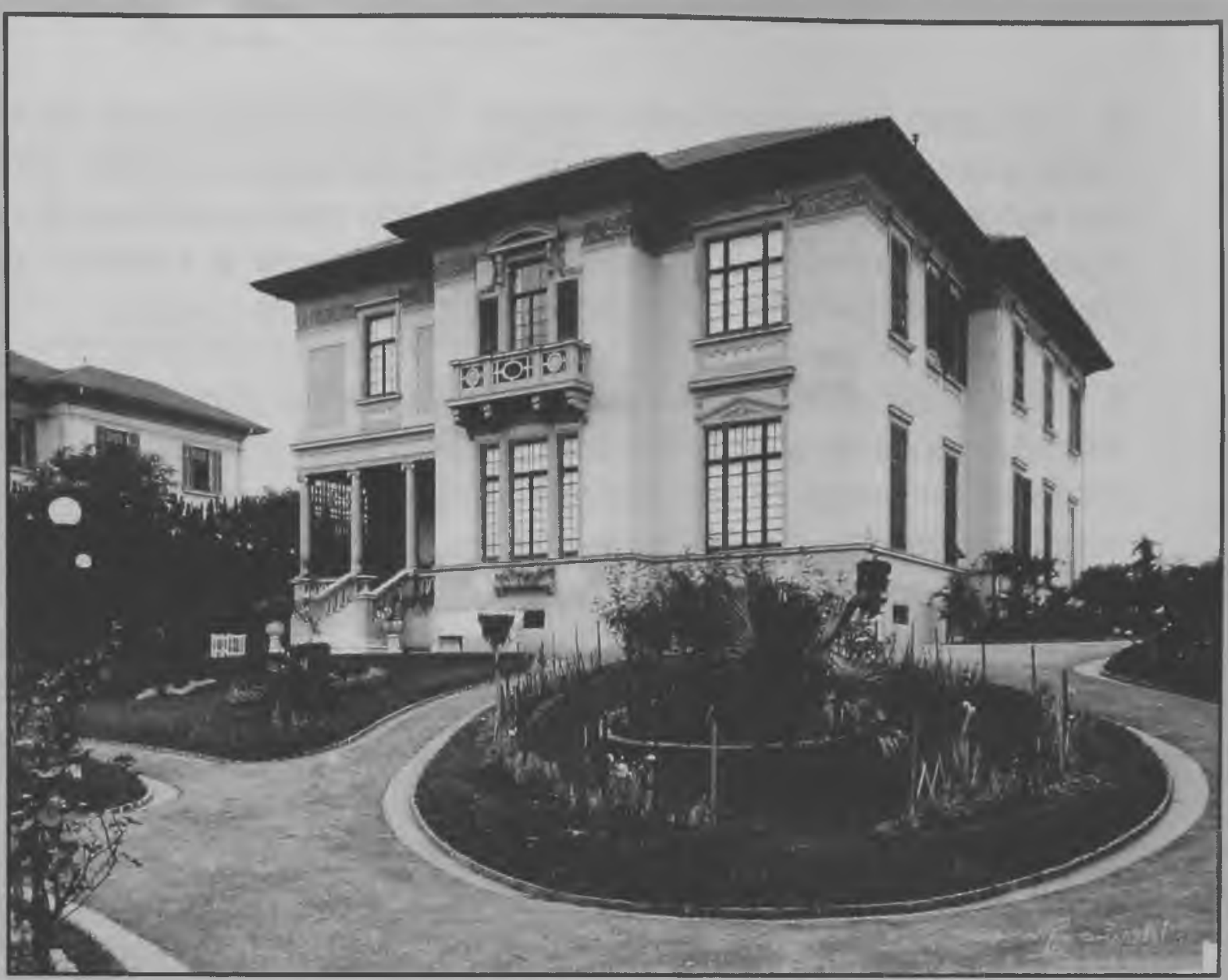

Figura 4: Vista do jardim de fundo da residência eclética Zeferino Guimarães Fonte: Arquivo FAUUSP

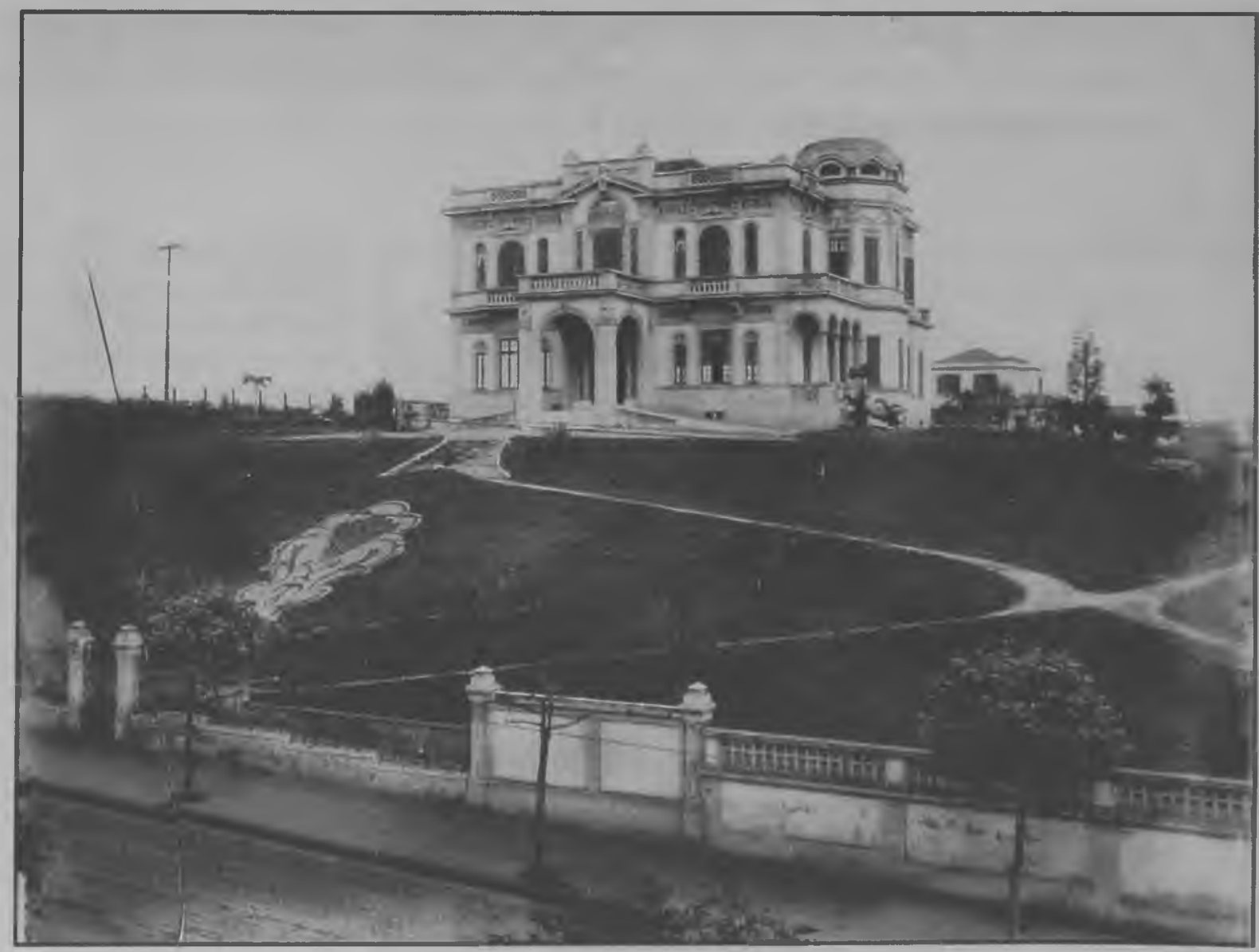

Figura 5: Palacete na av. Brigadeiro Luis Antônio, 300. Vista geral da implantação e do jardim frontal Fonte: Arquivo FAUUSP 


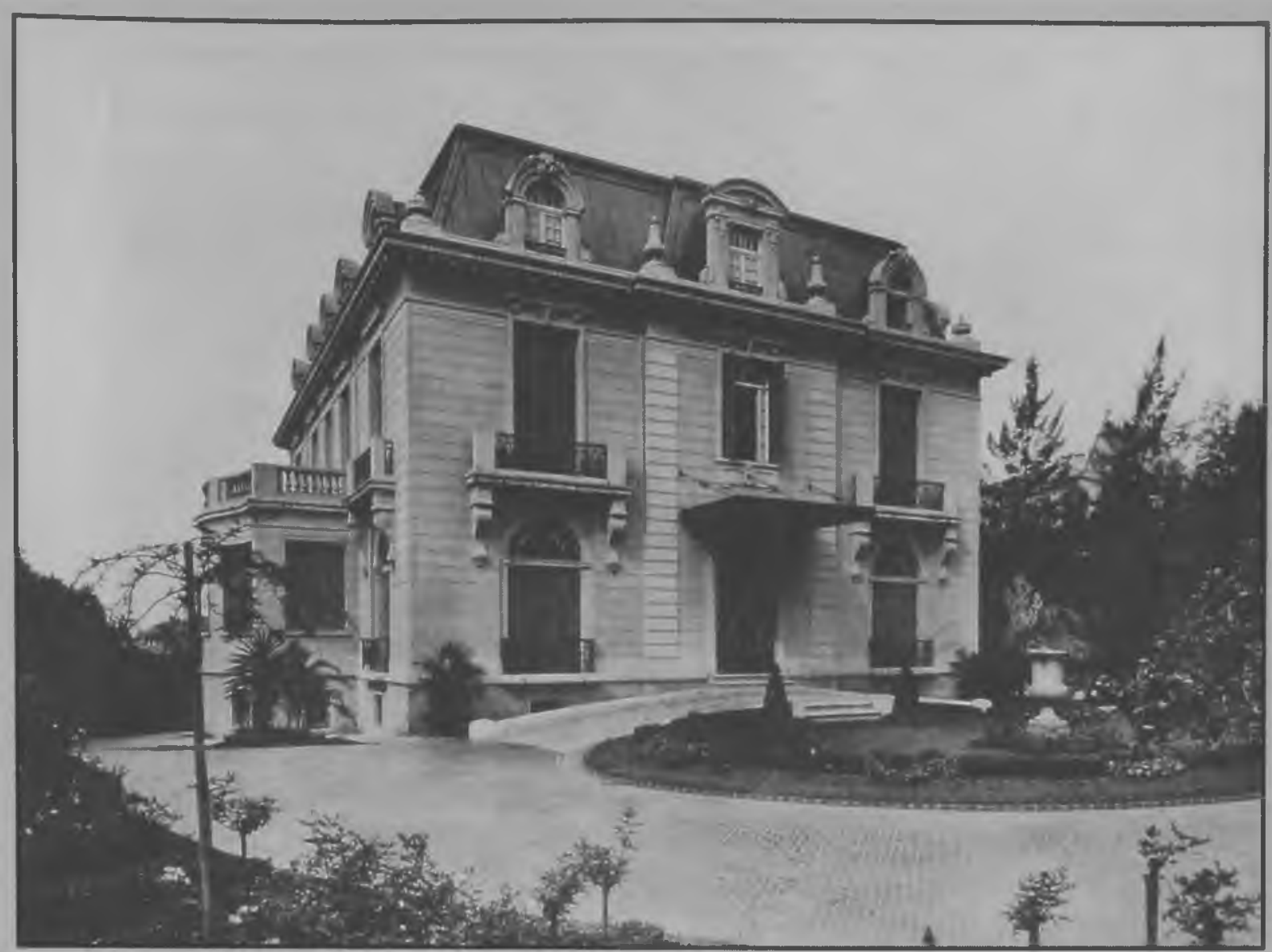

Figura 6: Vista do jardim frontal do palacete Mendonça Filho Fonte: Arquivo FAUUSP

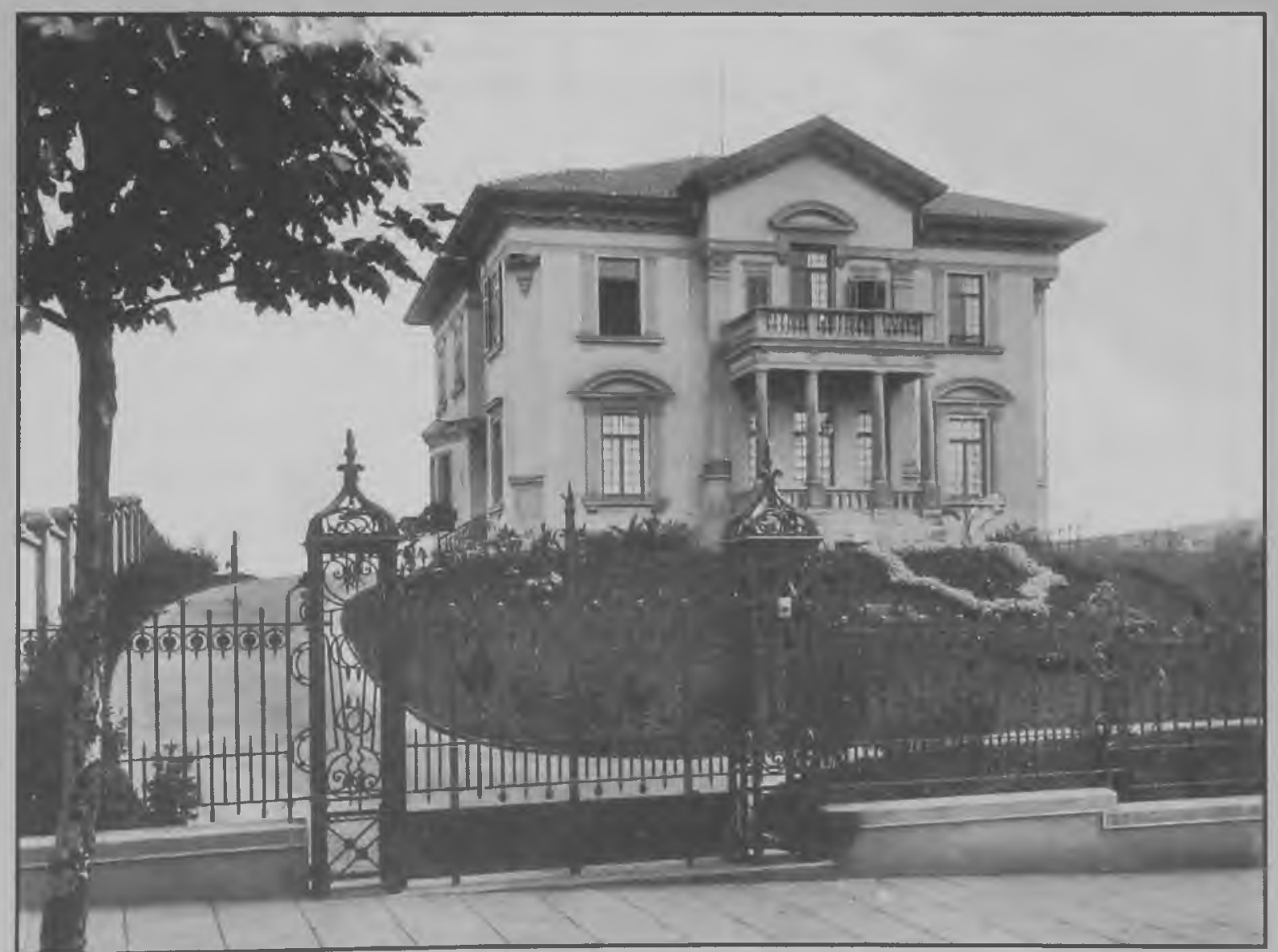

Figura 7: Vista frontal do palacete Bento Abreu Sampaio Vidal Fonte: Arquivo FAUUSP 


\section{Brutus \\ Abel \\ Fratuci \\ Pimentel}

Os Espaços Livres Residenciais na

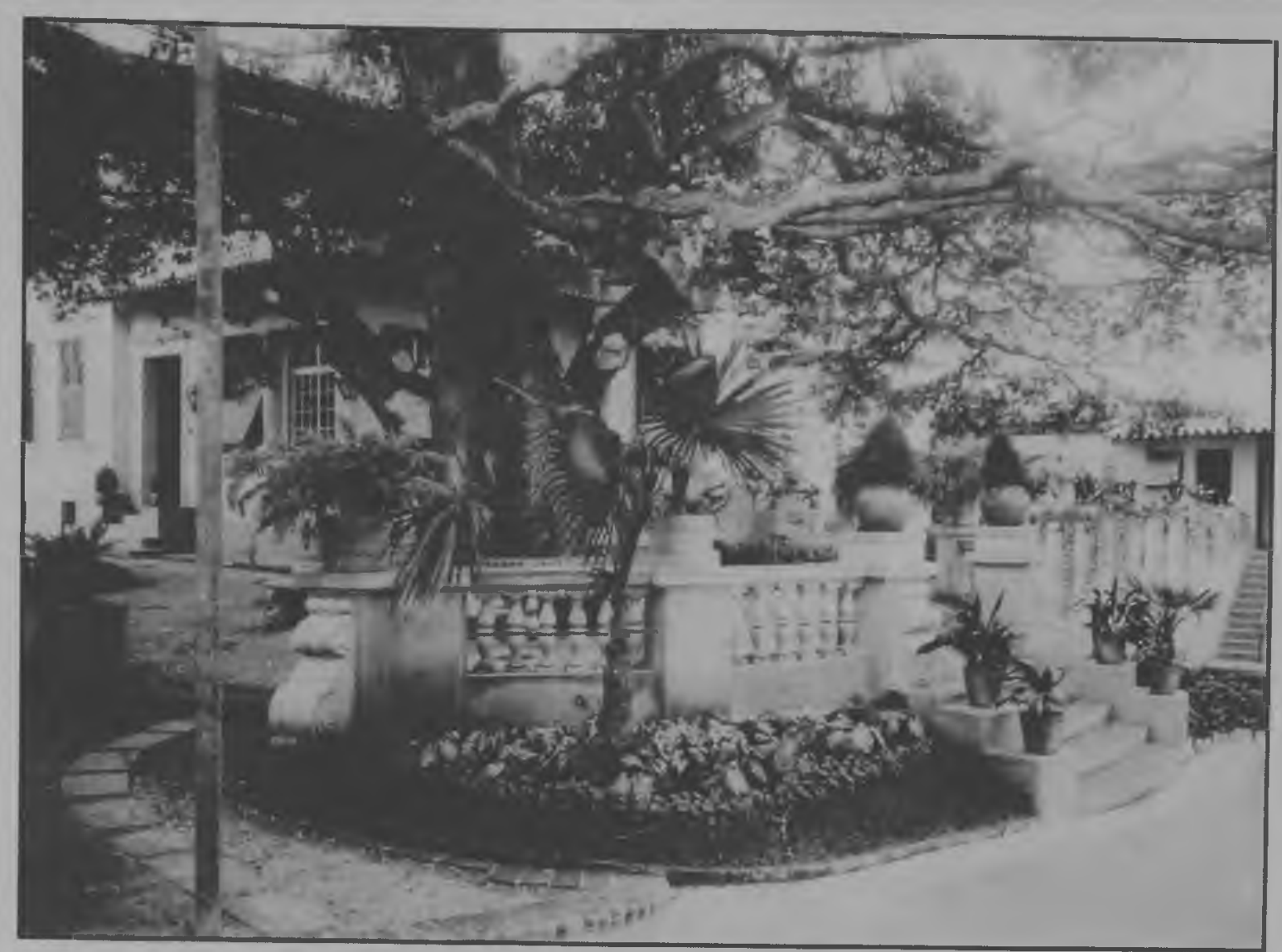

Figura 8: Detalhe do jardim da residência eclética Ricardo Severo Fonte: Arquivo FAUUSP

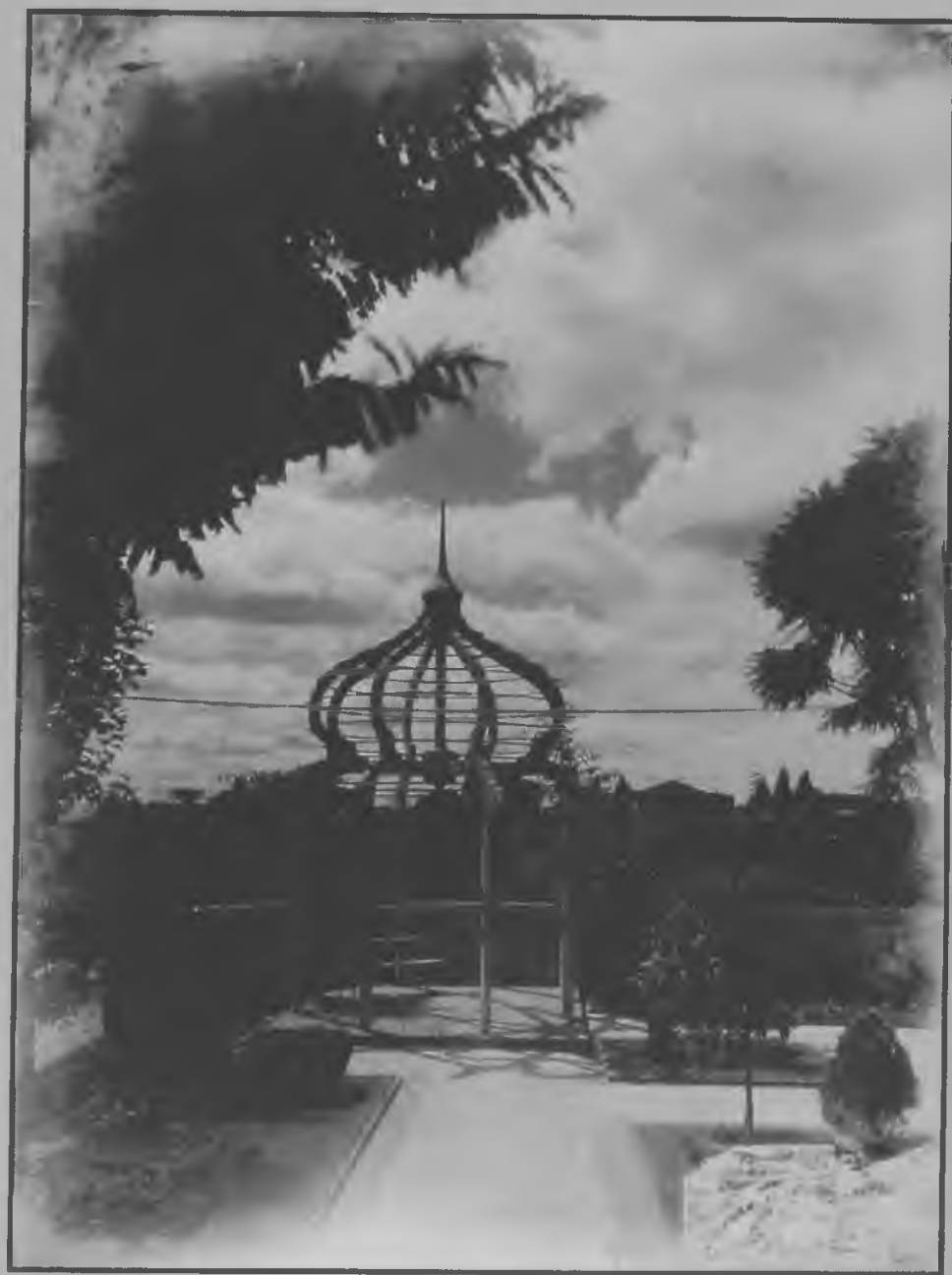

Figura 9: Residência Arnaldo Azevedo Villares Jardim lateral com pequeno coreto em estilo "árabe"

Fonte: Arquivo FAUUSP

\section{Paisagem Amblente Ensaios

São Paulo n. 11 p. 13 - 40 - dez. 1998 
Apesar destas inovações, a consolidação das estruturas urbanas atuais, com relaçāo à implantação mais comumente vista hoje em dia, somente se firmou no período do entreguerras, onde presenciamos definitivamente o fim do movimento eclético e, ainda que tardiamente, os primeiros índices do modernismo. Podemos dizer que temos a concretização definitiva do isolamento da casa da elite em meio a um jardim, o paralelismo rígido em relação aos limites do lote, o desaparecimento de pomares e hortas e o surgimento das edículas. Outro fator que transformou radicalmente a malha edificada em São Paulo foi o aparecimento dos arranha-céus, inicialmente comerciais e posteriormente prédios de apartamentos. Tais edificaçōes, de raízes norte-americanas, foram importantes transformadores da malha metropolitana, acarretando novas concepções de zoneamento.

Somente a partir dos anos 20 e 30 é que presenciamos as primeiras chamas do movimento moderno na arquitetura brasileira. A arquitetura paisagística, de caráter contemplativo, começa a ser repensada e o surgimento de uma maior funcionalidade organizacional dos programas arquitetônicos são estudados. Com o fim da Segunda Grande Guerra temos uma época de maturidade destas tendências. Na parte tecnológica observamos o boom industrial que leva a uma padronização dos elementos construtivos em larga escala e o crescimento da indústria automobilística.

O ecletismo em sua forma original desaparece, dando lugar a uma expressiva e idealista forma de concepção arquitetônica. A década de 50 foi o período de atuação de grandes paisagistas como Roberto Coelho Cardoso, Waldemar Cordeiro e Burle Manx, este último com maior atuação profissional na cidade do Rio de Janeiro. A influência americana se acentua na área do paisagismo e o tratamento dos espaços livres é feito de maneira a integrar os espaços abertos e fechados. Índice indispensável a esses projetos é a valorização dos elementos nacionais, principalmente com o uso da flora brasileira. O discurso em relação ao compromisso com a funcionalidade, com respeito às novas tecnologias como o carro (a garagem) e as novas formas de lazer como a piscina, torna-se mais estreito e, em certos termos, necessário, tomando lugar da “monumentalidade ultrapassada" dos casarões.

Roberto Coelho Cardoso confeccionou um caráter extremamente funcional ao paisagismo residencial em São Paulo. Influenciado pelo 
Brutus

Abel

Os Espaços Livres Residenciais na

Fratucl

PImentel

americano Garret Eckbo, propunha categoricamente que o paisagismo deveria se adequar de forma coerente ao sítio, à arquitetura e à natureza existente. Seu trabalho levou a arte de criar jardins a tomar uma posição preocupada também com o contexto social, conceituação esta denotada principalmente em seus trabalhos públicos.

Assim como Cardoso, Waldemar Cordeiro também deu enorme contribuição ao projeto dos espaços livres. Atuando em várias áreas da criação artística, foi um dos líderes teóricos do concretismo na história brasileira. Seus jardins eram concebidos como verdadeiras obras de arte, como tapeçarias ou pinturas. Priorizava os cenários para depois particularizar as plantas, características estas que deram início a uma maior liberdade de projetar entre os paisagistas nacionais.

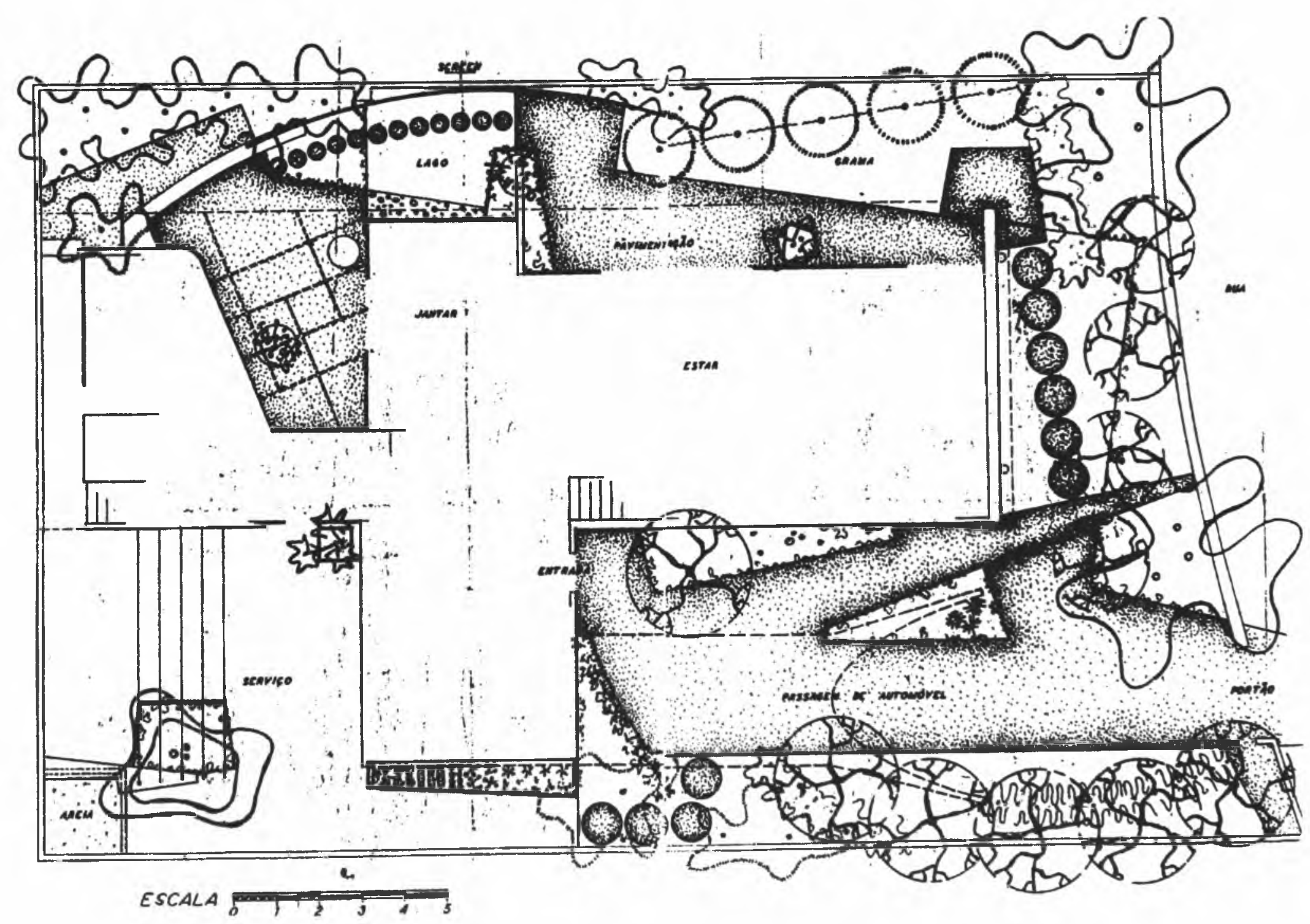

Figura 10: Projeto paisagístico moderno de Roberto Coelho Cardoso Fonte: Brutus Abel Fratuci Pimentel 
Em meio a todas estas mudanças físicas que a casa paulistana sofreu, temos em essência a transformação da estrutura familiar que se molda devido às novas formas de trabalho oriundas da industrialização em massa, do automóvel e da televisão, ditando, de certo modo, a nova ordem social de consumo: o estilo de vida americano em terras tupiniquins. Com essas profundas transformações a vida diária tornouse mais "rápida" e "estressante", deixando margem para que o homem buscasse novas formas de recreação na tentativa de equilibrar trabalho e lazer. Esta necessidade reflete-se profundamente na configuração espacial das residências e, em especial, nas suas áreas livres. Tornam-se mais pragmáticas, adequando-se ao bem-estar da família "moderna". Surgem de maneira corriqueira as piscinas, áreas para churrasco, de lazer e convívio social. Institui-se o "fim de semana" como o descanso da classe média e, portanto, as estruturas de lazer atingem altos índices de individualidade nas residências mais ricas onde temos desde quadras de tênis até canis particulares. Na década de 60 este ideário foi amadurecendo, a casa torna-se mais compacta eliminando-se a hierarquia entre as partes do programa da moradia. Na década seguinte, com o denominado "Milagre Brasileiro", a moradia particular adquiriu o sentido de ousadia estrutural da chamada Escola Paulista.

As novas casas começavam a reduzir-se a volumes geométricos cada vez mais simples; longe dos ornamentos do ecletismo "assumem" o paisagismo moderno americano definitivamente. Os recuos de frente e de fundo, apropriados como extensões dos espaços internos, transformaram-se em pátios e jardins particulares. O tratamento dos espaços livres, feito através de jardins com plantas tropicais, tornou-se elemento indispensável à nova arquitetura que surgia devido a uma tendência de valorização dos elementos nacionais. Grandes panos de vidros agora abrem-se vislumbrando uma natureza nacional e abundante, e o espaço aberto de convívio social estendeu-se por quase toda a área livre do terreno, dando ao jardim novas dimensões, graças a uma nova maneira de se projetar, eliminando o fachadismo para valorizar os volumes. $O$ compromisso com as relações mais presentes tornou-se evidente e por assim dizer necessário: nas novas relações de trabalho, transporte, lazer e, principalmente, nas tarefas domésticas. Provavelmente uma das mais importantes modificações deste período tenha sido a piscina, que a partir de então é utilizada em larga escala uma marca das residências da elite paulistana. Estas novas e importantes modificações, em contrapartida, ocorreram somente nas classes mais favorecidas da sociedade, portanto uma generalização de

São Paulo n. 11 p. 13 - 40 - dez. 1998 

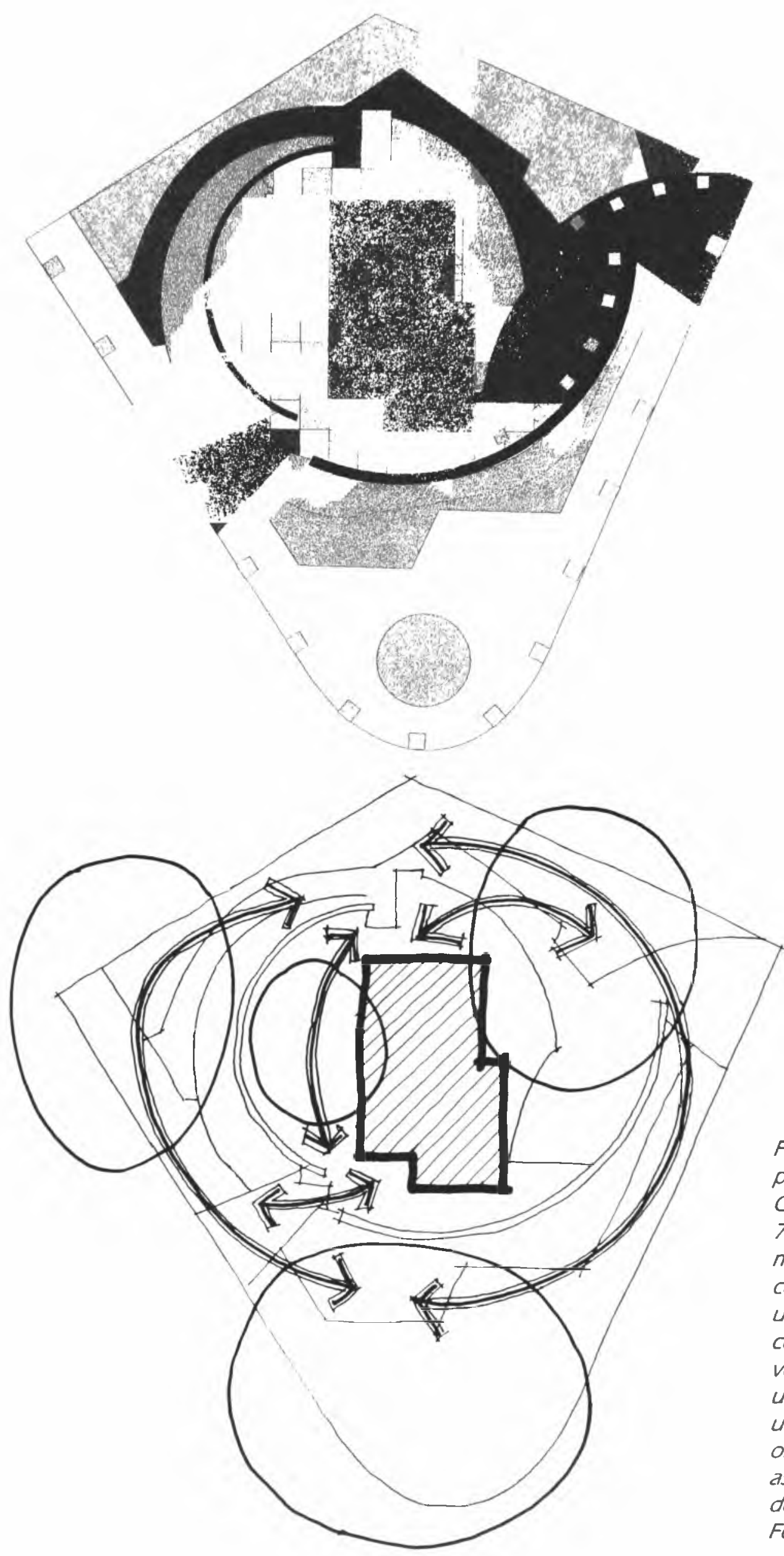

Figura 11: A casa de Claudia, de projeto paisagístico de Susan Osborn Coelho data da década de 70, época do auge das residências modernas em sua perspectiva construtiva. A residência apresenta uma implantação de esquina centralizada no lote onde podemos ver, claramente, a configuração de uma área paisagística moderna utilizando-se de elementos orgânicos como curvas e assimetrias com relação do desenho do piso

Fonte: Brutus Abel Fratuci Pimentel 

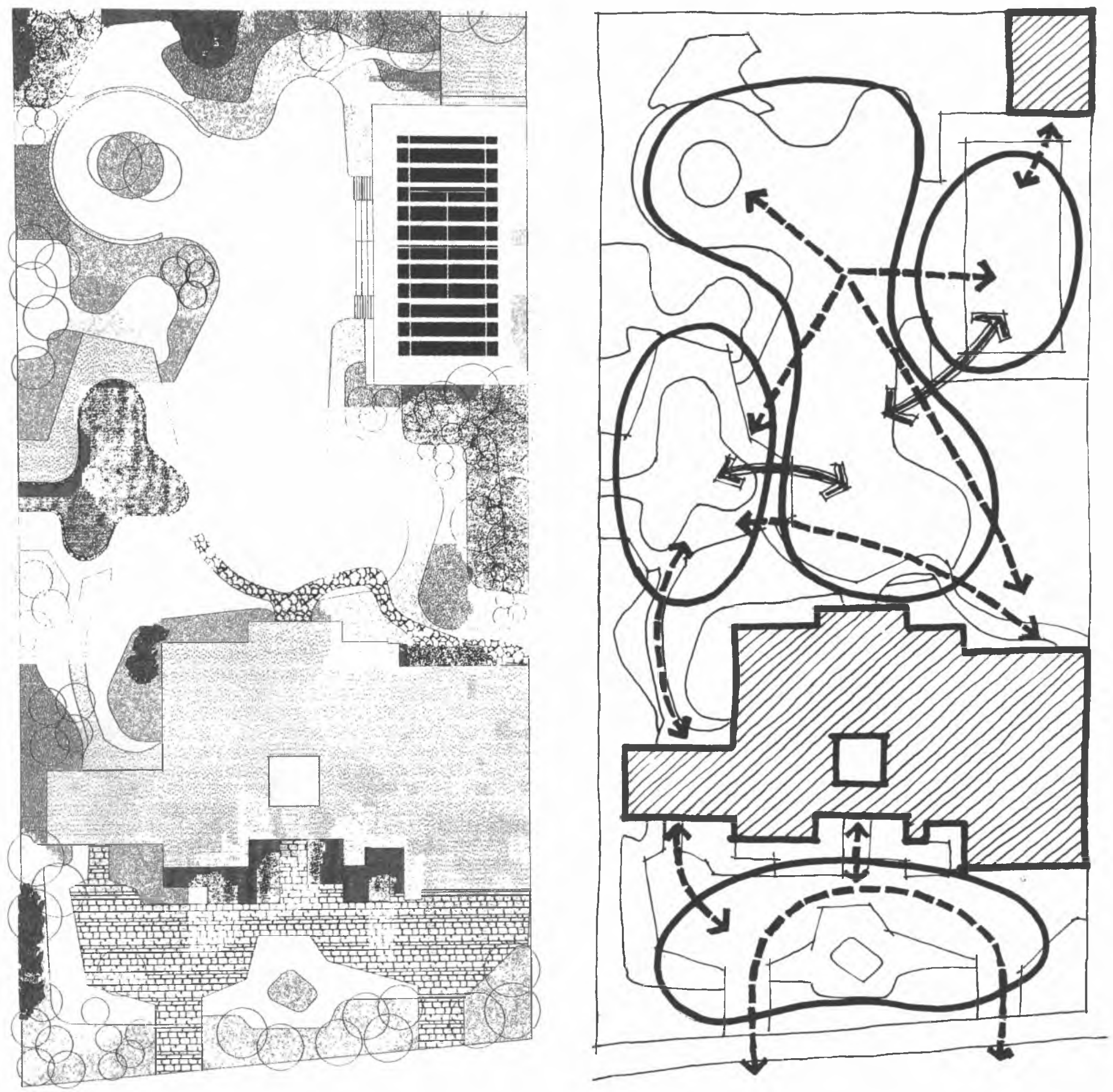

Figura 12: A residência de Antônio Ermírio de Morais data da década de 80, onde temos o forte desenvolvimento dos condomínios fechados. Esta residência de alto padrão aquisitivo possui forte traço estilístico de linhas orgânicas e de desenhos de piso com projeto assinado por Burle Manx. A área livre é tratada com todas as exigências que a morada contemporânea de alto padrão demanda: quadra de tênis, canil e piscina, além de uma forte área verde circundando a casa

Fonte: Brutus Abel Fratuci Pimentel 
Brutus

Abel

Fratuci

Pimentel

todas tendências seria de todo um erro. O movimento moderno, do ponto de vista da arquitetura residencial, tornou-se, posteriormente, um novo estilo na mentalidade eclética que efetivamente nunca deixou de existir

Podemos, portanto, caracterizar os espaços livres da casa após o período moderno com relação aos itens já vistos do palacete paulistano, com os seguintes aspectos:

1 - Jardins de influência americana; propõem uma integração maior com a arquitetura edificada. Sua intenção é a valorização do lazer.

2 - Na entrada da casa o quadro estilístico, valorizado anteriormente, deixa de ser tão importante dando lugar a uma maior praticidade com a presença da garagem ${ }^{2}$

3 - As áreas de serviço não são tão desvalorizadas, tendem a ser mais práticas para facilitar o trabalho doméstico.

4 - A cultura que mais influi no estilo de vida paulista é a americana as áreas livres são de desenho americano - apesar de toda influência do movimento moderno derivar em grande parte da Europa.

5 - Há uma "estética moderna" mais independente do traçado clássico.

Figura 13: Residência dos anos 50 publicada na revista Acrópole. Esta residência, no Pacaembú, tem projeto e construção de Rubem Monteiro e é de propriedade de Arthur Kauffman Fonte: Revista Acrópole
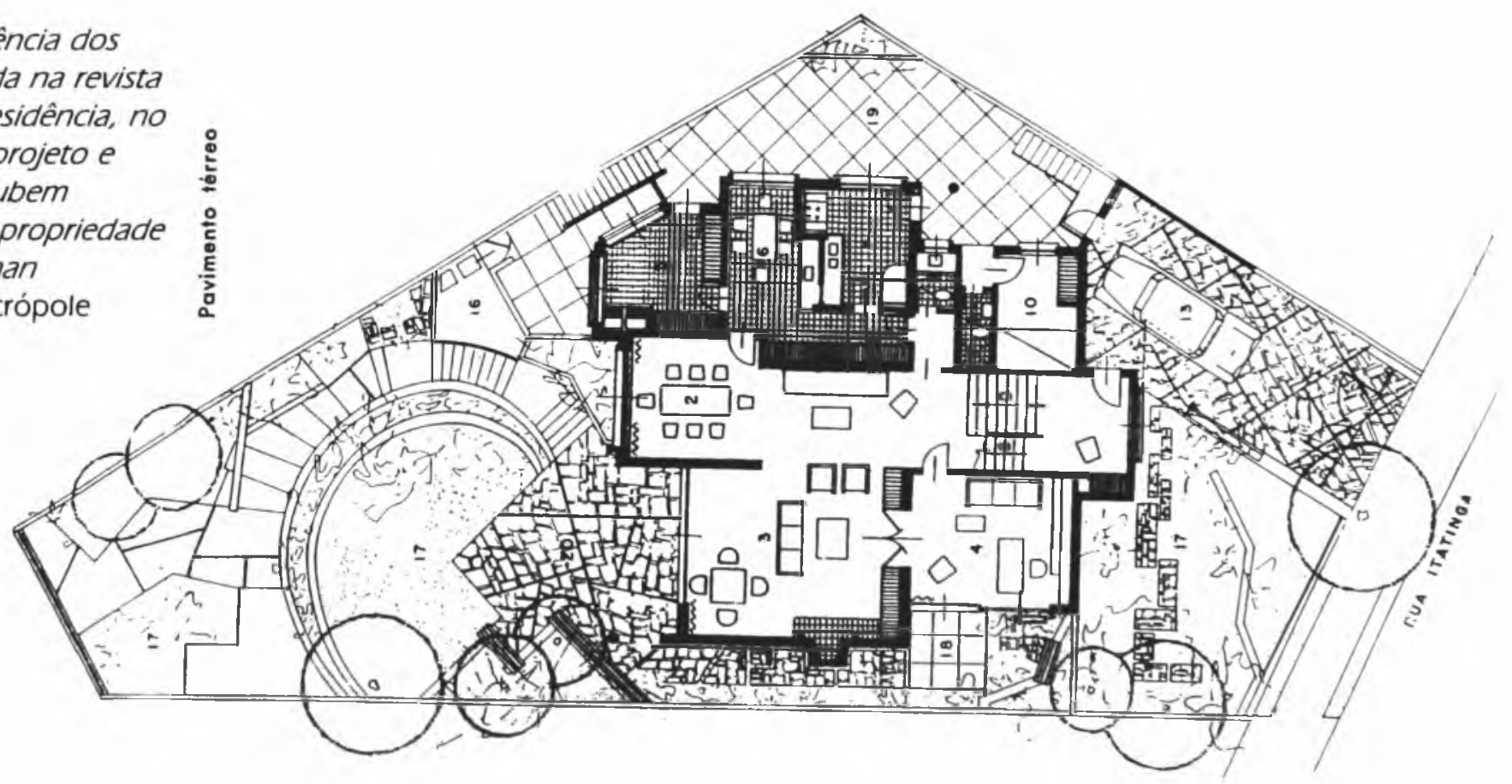

(2) Neste caso não podemos dizer que o valor social imagético da entrada da residência tenha perdido sua força por completo, apenas que os estilos tornaram-se mais "soltos" e a imagem padrão da casa "moderna" paulistana ganhou o carro como presença indiscutível.

\begin{tabular}{|l|l|l|}
\hline 28 & $\begin{array}{l}\text { Paisagem } \\
\text { Ambiente } \\
\text { Ensaios } \\
11\end{array}$ & São Paulo n. 11 p. $13-40$ dez. 1998 \\
\cline { 2 - 3 } & &
\end{tabular}




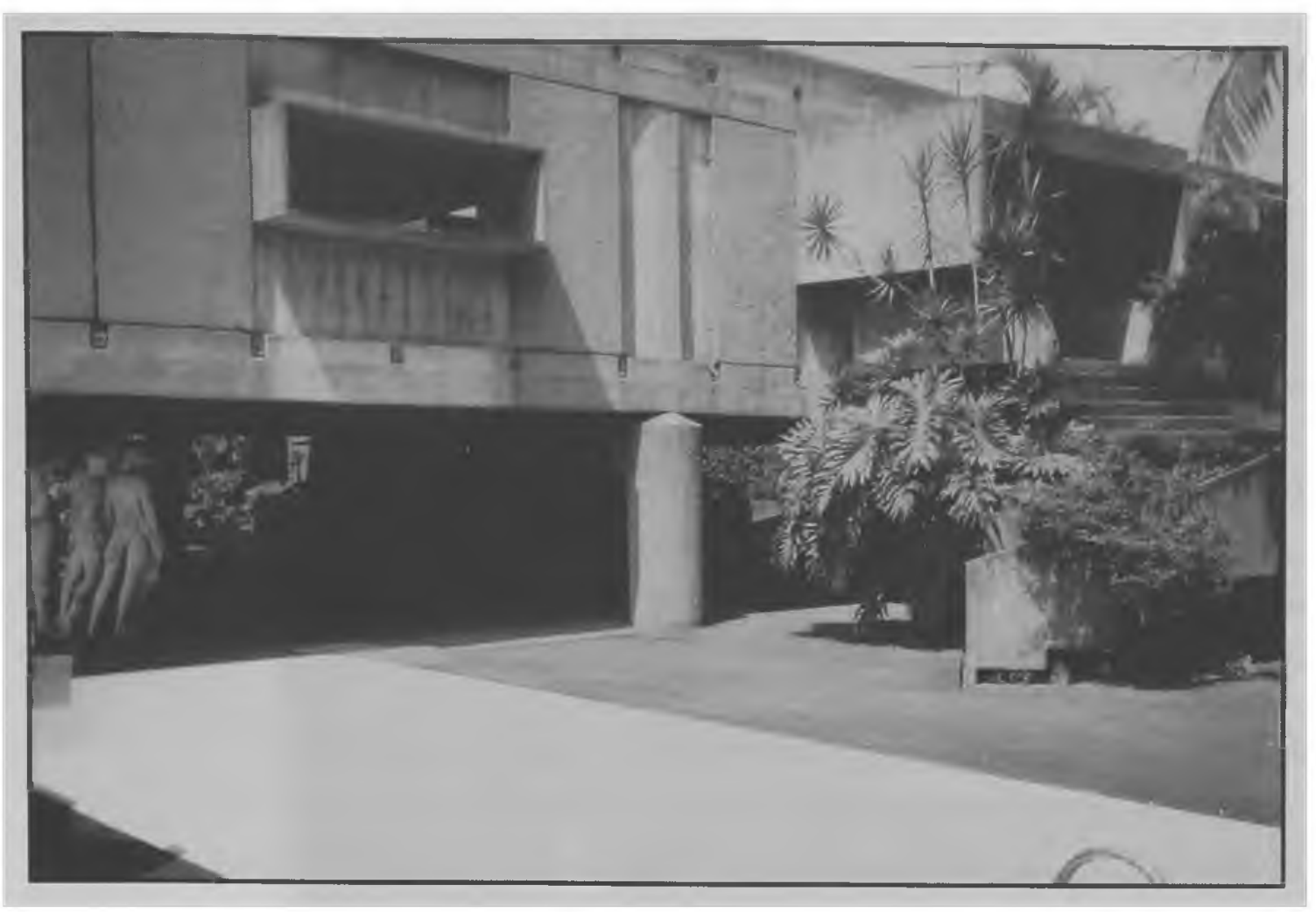

Figura 14: Residência moderna elevada sobre pilotis projetada por Paulo Mendes da Rocha Fonte: Brutus Abel Fratuci Pimentel

Considerando-se, estruturalmente, o caráter de implantação, ou seja, o elemento a priori de definição dos espaços livres, a implantação típica do casarão define-se pela valorização da entrada social, na maioria das vezes dada de forma circular para que o carro (carroça) possa dar um passeio pelo jardim frontal. A implantação "moderna" é, neste aspecto. mais direta: modifica-se primeiramente com o surgimento da garagem, portanto, a entrada deve ser prática como a "vida moderna" exige - de maneira alguma de forma suntuosa. Há uma valorização do espaço por detrás dos muros. Os espaços de socialização (piscina, churrasqueiras, solarium, etc.) são escondidos do público. Não importa mais mostrar a sofisticação da residência como um grande outdoor estilístico de entrada. $O$ foco principal de atenção transfere-se para o seu interior ${ }^{3}$ através de uma maior articulação entre os espaços externos e internos.

A casa paulistana, comumente vista hoje em dia nas áreas consideradas de "classe média" apresenta-se como um misto das duas formas vistas acima. Os palacetes já não existem mais, porém ainda persistem em quantidade, casas de estilo derivadas do ecletismo, reduçōes dos

(3) O caráter desta nova área livre é de puro isolamento com relação à cidade, não é imagem pública sendo somente servil aos moradores da casa. As residências nos condomínios fechados extrapolam esta condição, pois dentro de seu território não possuem muros, mas estão encerradas dentro de um "Iugar" semipúblico. 
Brutus

Abel

Os Espaços Livres Residenciais na

Fratuci

Pimentel

grandes casarōes adaptados para o carro e o modo de vida contemporâneo. Com programas mais acessíveis reformulam-se ainda às necessidades residenciais atuais, apesar de seu aspecto visualmente estilístico.

A arquitetura paisagística contemporânea curva-se diante da multidisciplinariedade atual, na qual o homem vive e trabalha. Suas casas possuem espaços cada vez mais multifuncionais, nos quais devem ser pesadas a utilização de cada ambiente no decorrer dos anos, na sua articulação e orientação e, acima de tudo, no bem-estar humano em uma sociedade ligada à mídia e dependente de uma variedade de artefatos tecnológicos.

Na cronologia deste século, podemos agora perceber com mais nitidez que as residências e áreas livres particulares podem ser organizadas em duas etapas com características essenciais. A primeira, a do clássico e tradicional palacete paulistano, com sua face européia, (re)velando toda uma sociedade burguesa, refletida em seus jardins luxuosos, cujo caráter foi o de "elevar" o valor do palacete e do seu proprietário. A segunda veio da transformação das idéias advindas do movimento moderno e das concepções norte-americanas, onde o convívio em áreas livres torna-se mais privativo e isolado.

Acima do valor social dado para a aparência da moradia, tão importante no período eclético ${ }^{4}$. o paisagismo contemporâneo encerra em si mesmo sua função de integração à casa (ou deveria ser assim). Pode-se interpretar que tal valor social é transferido para outros signos surgidos em nossa sociedade tecnológica, como a televisāo e principalmente o automóvel. Claramente isto não desmente que o fator da existência de um belo jardim possa denotar certo poder aquisitivo, porém o objeto jardim não possui a mesma conotação forte de outros tempos. O jardim tornou-se algo mais de união arquitetural e não mais de "simples moldura" Seu ponto de interesse deve bastar-se por si só, tornando-o elemento adjunto da casa e não complemento.

(4) É importante ressaltar que, em sua maioria, grandes edifícios comerciais ocupam exatamente o mesmo lote que outrora ocuparam antigos casarōes, estes últimos em menores proporçōes que o primeiro - uma casa para cada prédio - o exemplo mais típico desta transformação é a avenida Paulista. 


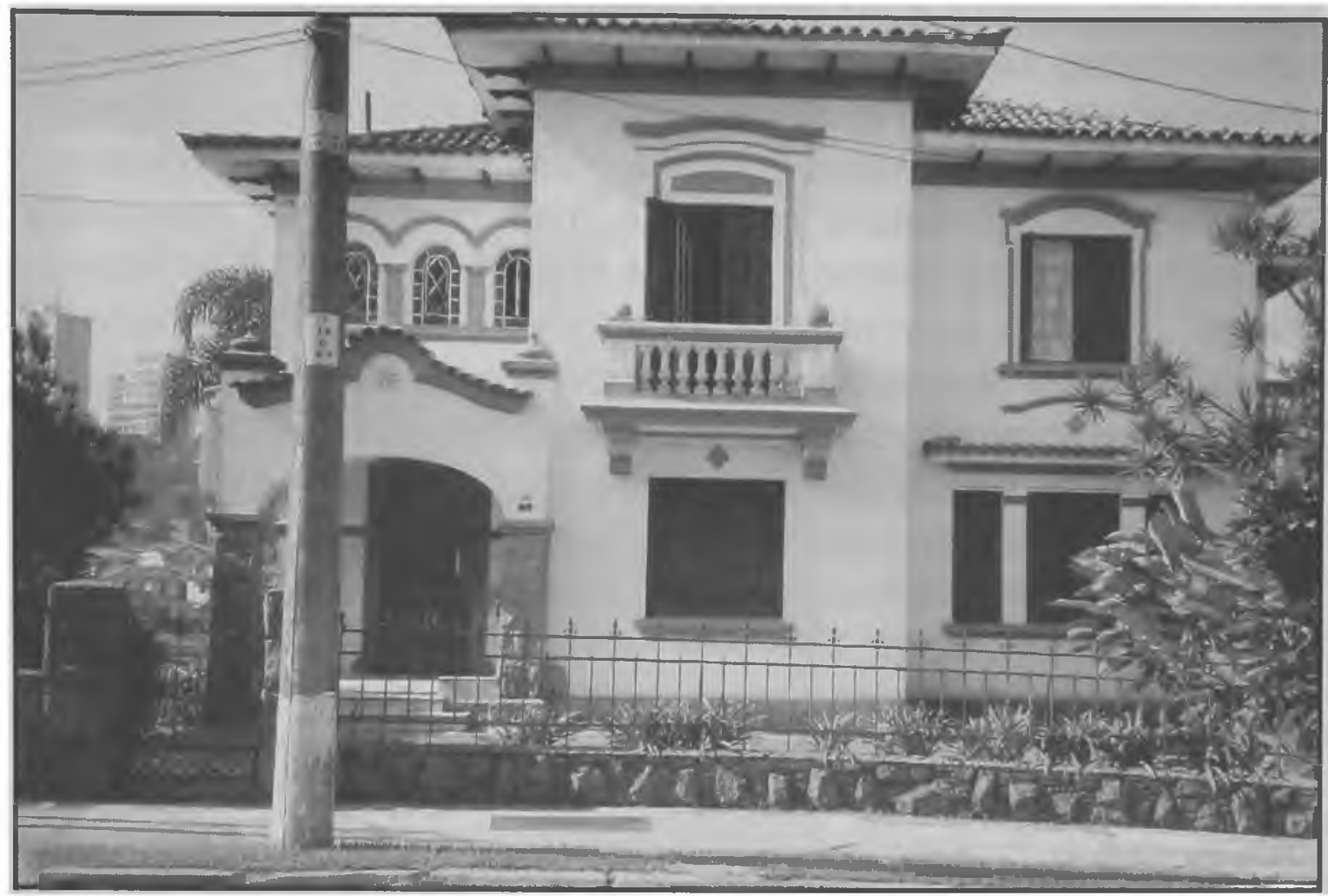

Figura 15: Residência da década de 50, no bairro da Vila Mariana em moldes de implantação eclética

Fonte: Brutus Abel Fratuci Pimentel

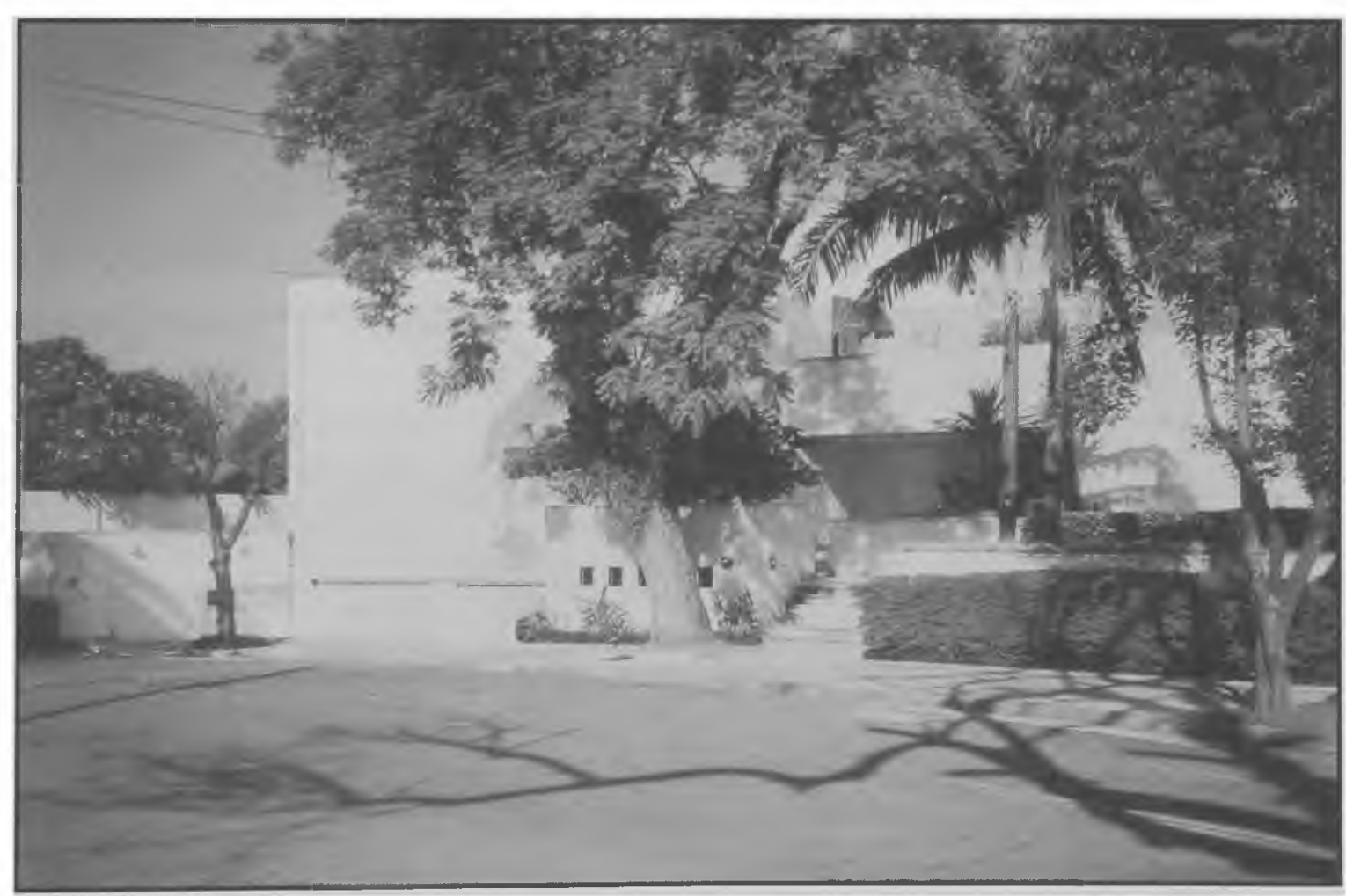

Figura 16: Residência no Pacaembú com linhas despojadas de ornamentos Fonte: Brutus Abel Fratuci Pimentel 
Brutus

Abel

Fratuci

Pimentel

Após toda a "transformação" que o modernismo trouxe a São Paulo (pelo menos quanto à sua proposta teórica), as residências paulistanas apresentaram um panorama bastante diversificado de estilos e propostas. Atualmente qualquer residência que venha a ser projetada segue padrões diversos segundo o projetista, à vontade e necessidades do cliente. A arquitetura tornou-se mais comercial e imediatista, esquecendo-se, em muitos casos, de relevâncias estéticas e "urbanosociais" Há uma supervalorização dos elementos que sensibilizem o conforto físico, tendendo a um "exagero luxuoso" Aliado à alta tecnologia e ao padrão de segurança que se instalou como a resistência à violência, as residências de alto padrão tornaram-se verdadeiros fortes, com grandes muralhas quando localizadas em áreas mais centrais. Os espaços livres foram aprisionados e sua função se restringiu a um refúgio da cidade.

A violência e a procura de melhores lugares, com melhor qualidade de vida, leva hoje à formação de verdadeiros "feudos modernos". Antes a criação dos bairros-jardins, agora com a presença de condomínios fechados como Alphaville, que possuem verdadeira infra-estrutura autônoma com áreas de lazer coletivo e de serviço quase completos, longe do centro da cidade. Os lotes, geralmente de grandes dimensões, favorecem o desenvolvimento de uma poderosa indústria imobiliária, que vem crescendo não só nestas áreas, mas que especulam também em regiões mais centrais, assim criou-se uma hierarquização social das áreas residenciais na malha urbana, acarretando em grandes problemas de ordem pública para a cidade, principalmente na área do transporte.

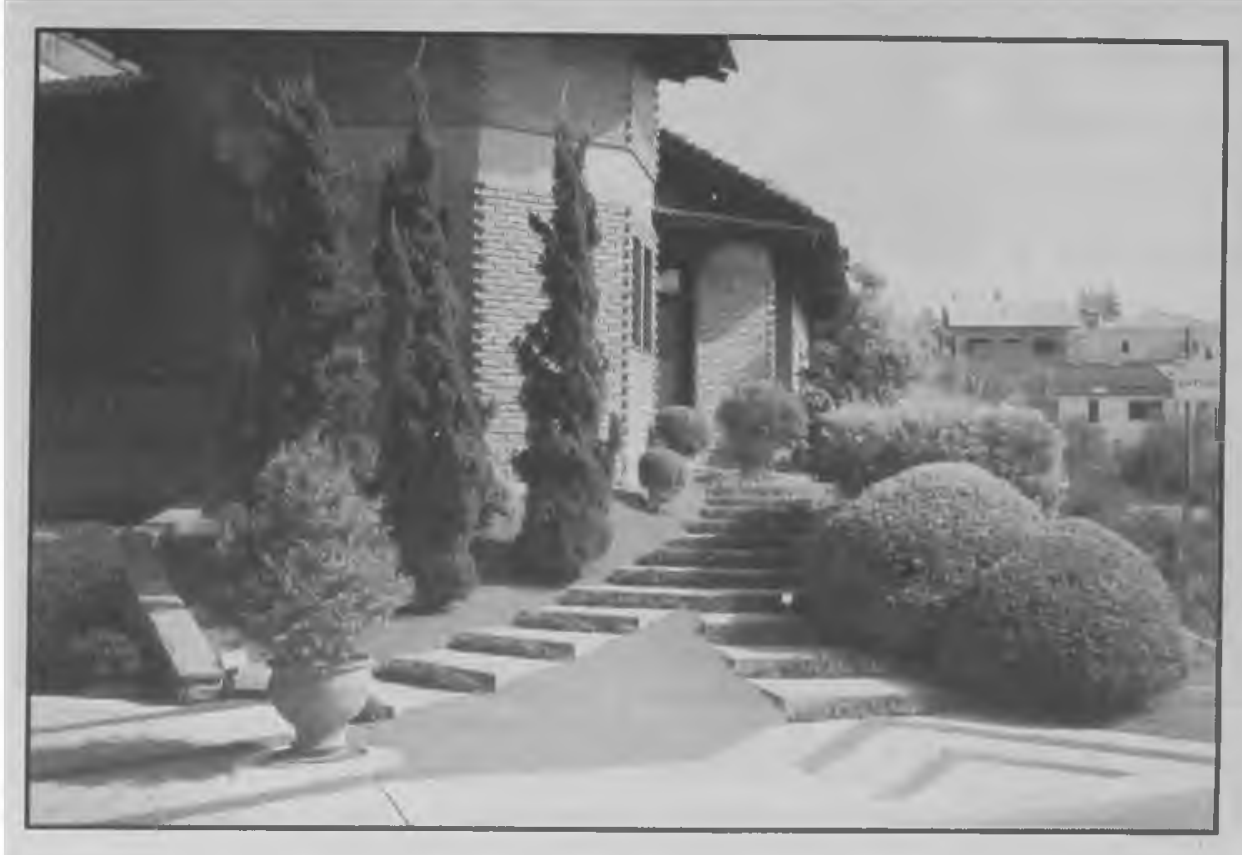

Figura 17: Residência em Alphaville. Detalhe de jardim externo Fonte: Brutus Abel Fratuci Pimentel 

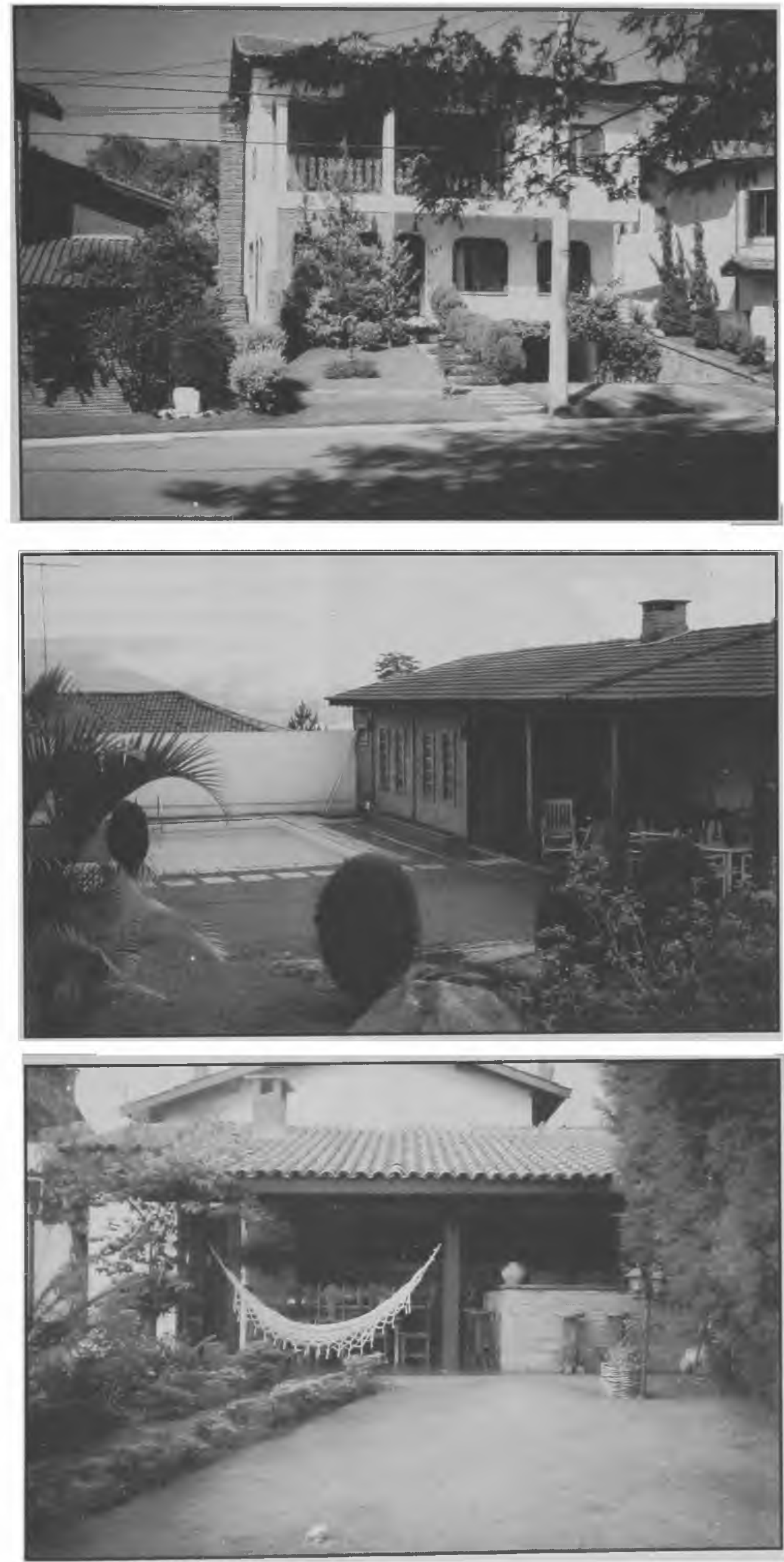

Figura 18: Residência típica de condomínio fechado. Note que as residências não possuem muros. lembrando o tipico subúrbio americano Fonte: Brutus Abel Fratuci Pimentel

Figura 19: Típica residência em condomínio fechado, onde temos ao fundo toda uma estrutura de área de lazer: gramado com churrasqueira coberta e a piscina

Fonte: Brutus Abel Fratuci Pimentel

Figura 20: Residência em condomínio fechado, onde observamos que a edícula da casa mantém uma estrutura de lazer Fonte: Brutus Abel Fratuci Pimentel 
Ao vermos a malha periférica da cidade, constatamos que as residências mais pobres assumem configurações muito semelhantes às das existentes no século 19, guardando as devidas proporções tecnológicas. Na essência, a qualidade de vida nestas áreas não se apresenta diferente daqueles tempos. Há pouca insolação e os limites dos lotes não são respeitados. Os poucos espaços livres que restam são apropriados de maneira criativa no arcabouço em que se apresenta: a laje para o churrasco, o canto para o bate-papo e a cerveja, a garagem também como depósito, o canteiro que a dona de casa rega e cuida (?). Ao que parece, portanto, o desenho eclético e sua função propagandista classicizante ainda não perdeu sua força, mostrando sua estrutura arquitetônica e paisagística em áreas mais periféricas da

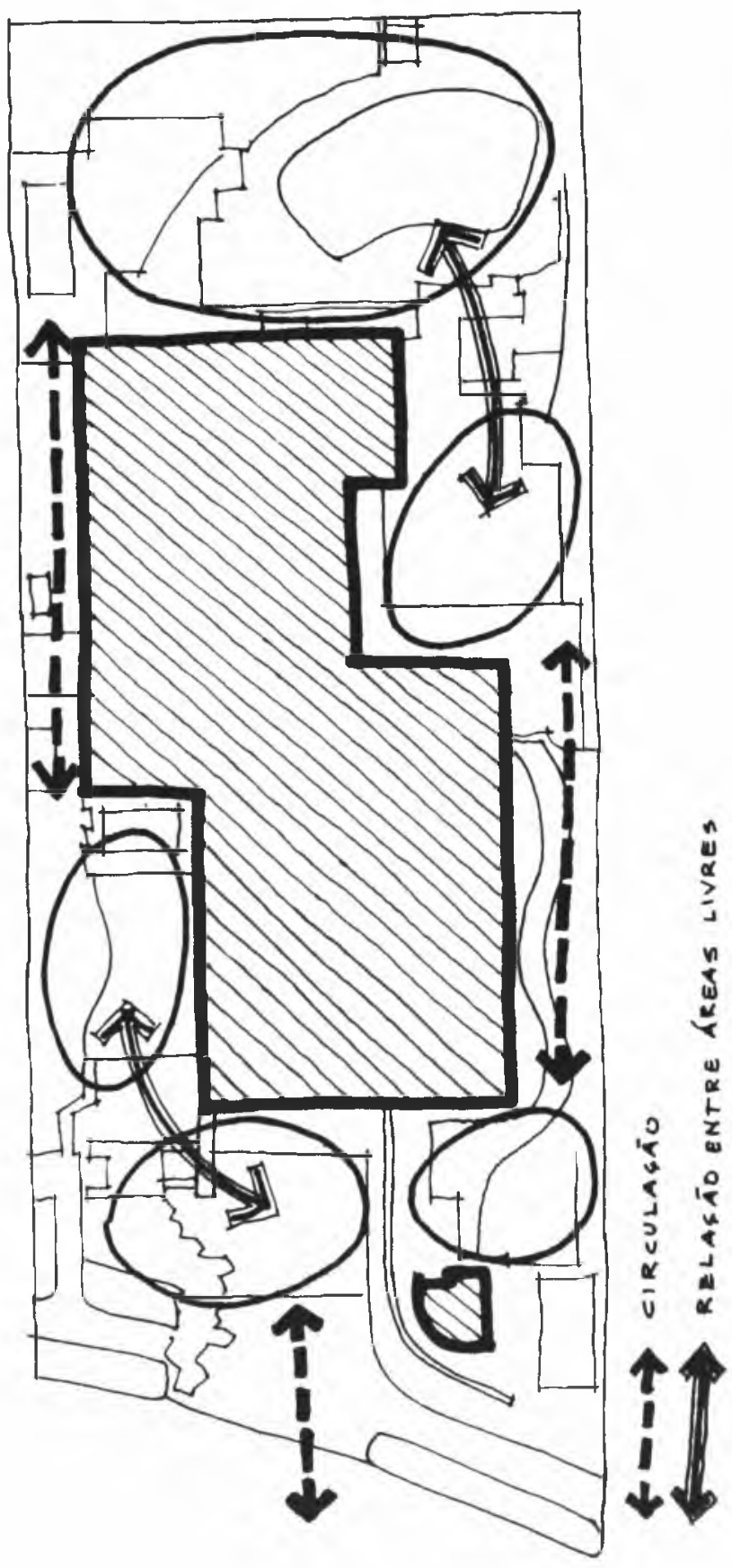

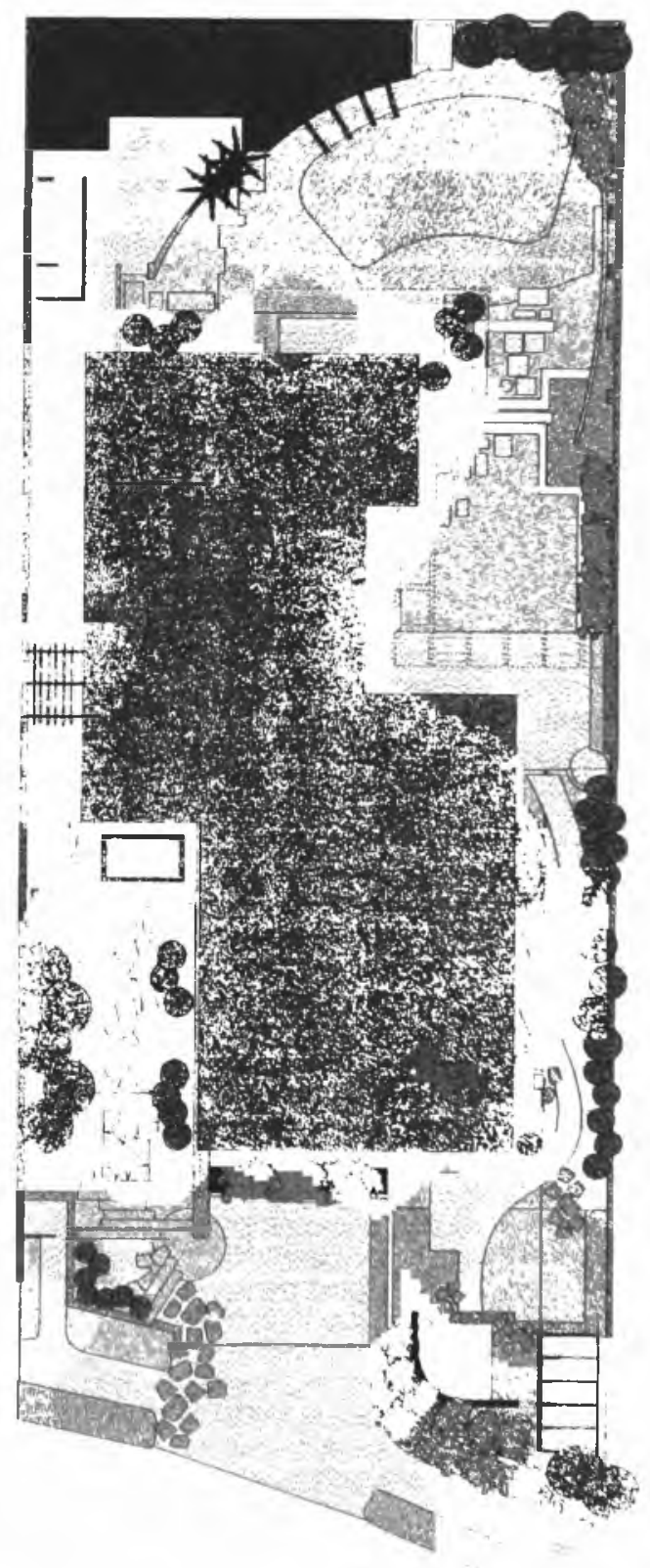

Figura 21: A residência de projeto paisagístico de Luciano Fiaschi ldécada de 901 possui um projeto extremamente elaborado na formação de diferenciadas áreas livres em torno da casa Fonte: Brutus Abel Fratuci Pimentel 
cidade, como também em casarões que hoje se erguem em função de um novo "ecletismo" ao qual o moderno tornou-se mais um estilo a ser integrado.

\section{P adrōes morfológicos do fim do século 19
ao fim do século 20}

Estas quatro ilustrações mostram a evolução que a residência paulistana sofreu em fins do século passado até o presente. $O$ estudo ilustrativo é da casa mais significativa em São Paulo, ou seja, daquela que possui o paisagístico particular enquanto forma planejada. Notase, no transcurso cronológico, que o desenvolvimento das diversas tipologias modifica a paisagem urbana, índice da importância da configuração espacial da cidade enquanto ponto de vista das construções particulares.

A primeira ilustração (figura 22) remete ao fim do século 19 quando, já com o crescimento urbano mais acelerado e com a cultura do café, os

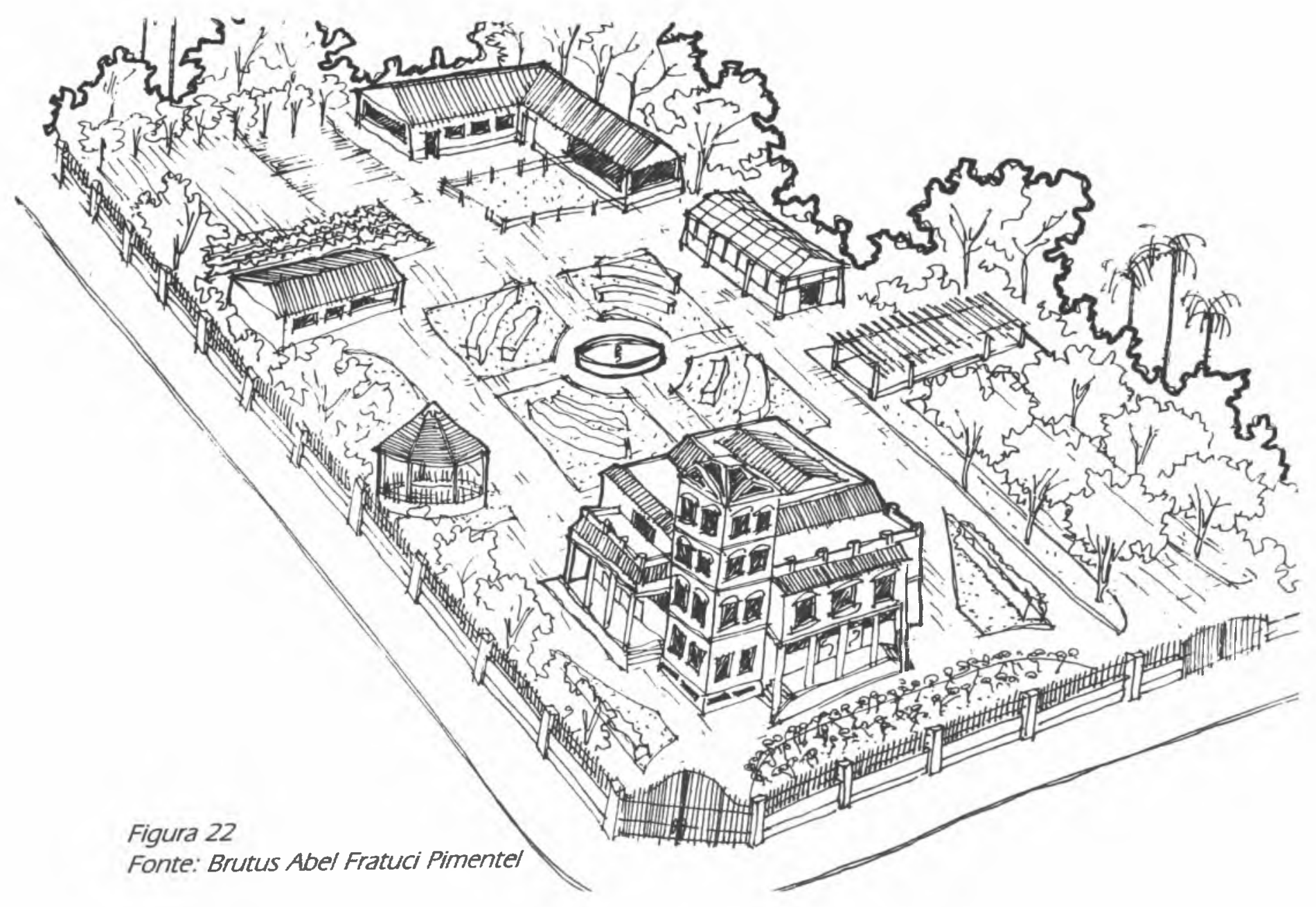

São Paulo n. 11 p. 13 - 40 dez. 1998 
novos meios de produção transformaram as chácaras inicialmente agrícolas. É a chácara urbana. Possuindo cercas e muros, seu lote é extremamente grande, e apesar da malha urbana começar a cercá-la, ela encerra em si valores e estruturas físicas claramente rurais. Aos fundos há desde hortas, pomares, galinheiros, com jardins em estilo europeu. Ela é um misto de uma parte transitória da porção rural que paulatinamente se findava com a porção urbana.

A população cresce e os grandes espaços são retalhados para as novas moradias. As chácaras têm seus terrenos loteados, e muitas delas têm sua edificação principal demolida. Neste caso (figura 23) manteve-se o casarão da chácara. Ele transforma-se em "palacete" e ao redor são construídos outros casarões, todos em estilo eclético.

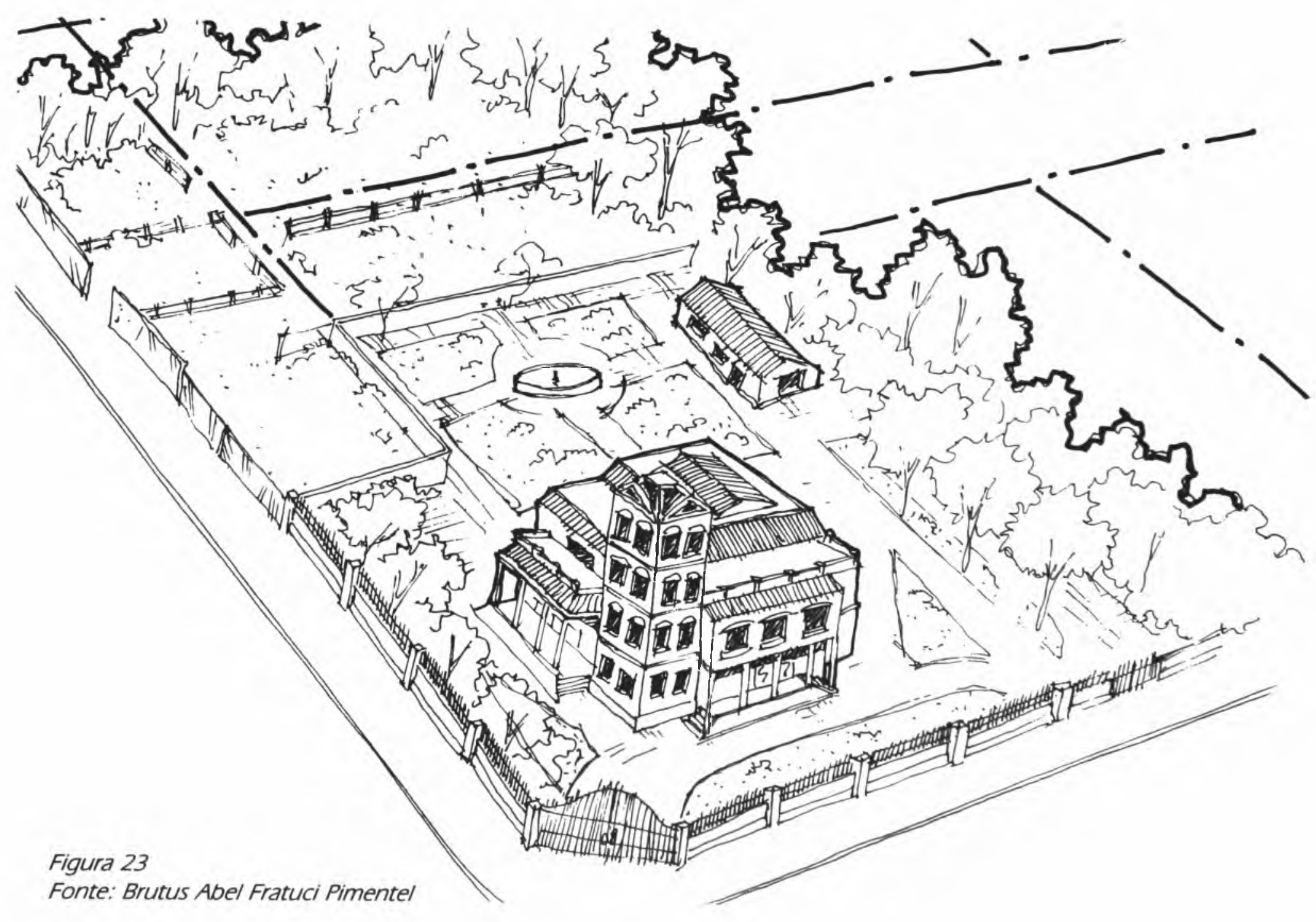

Fonte: Brutus Abel Fratuci Pimentel

\begin{tabular}{|l|l|}
\hline 36 & Paisagem \\
\hline & Ambiente \\
& Ensaios \\
11 \\
\hline
\end{tabular}

São Paulo n. 11 p. 1340 - dez. 1998 
Os palacetes já não são tão mais úteis aos ricos proprietários (figura 24), pois a própria riqueza muda de mãos. É o fim do monopólio do café, início da industrialização e do automóvel como meio de transporte em massa. Somente as pequenas casas de cunho estilístico, pertencentes a pequenos proprietários, sobrevivem. Elas co-habitam junto às novas residências que já são de influência moderna. Os jardins frontais ecléticos tendem a ser esquecidos. Temos os jardins de fundo, escondidos da vista dos transeuntes e o jardim-canteiro frontal muitas vezes sem muros, valorizando mais a própria arquitetura da casa. É novamente um período de transição onde custou-se a aceitar e a incorporar as novas soluções urbanas e arquitetônicas já adotadas na Europa.

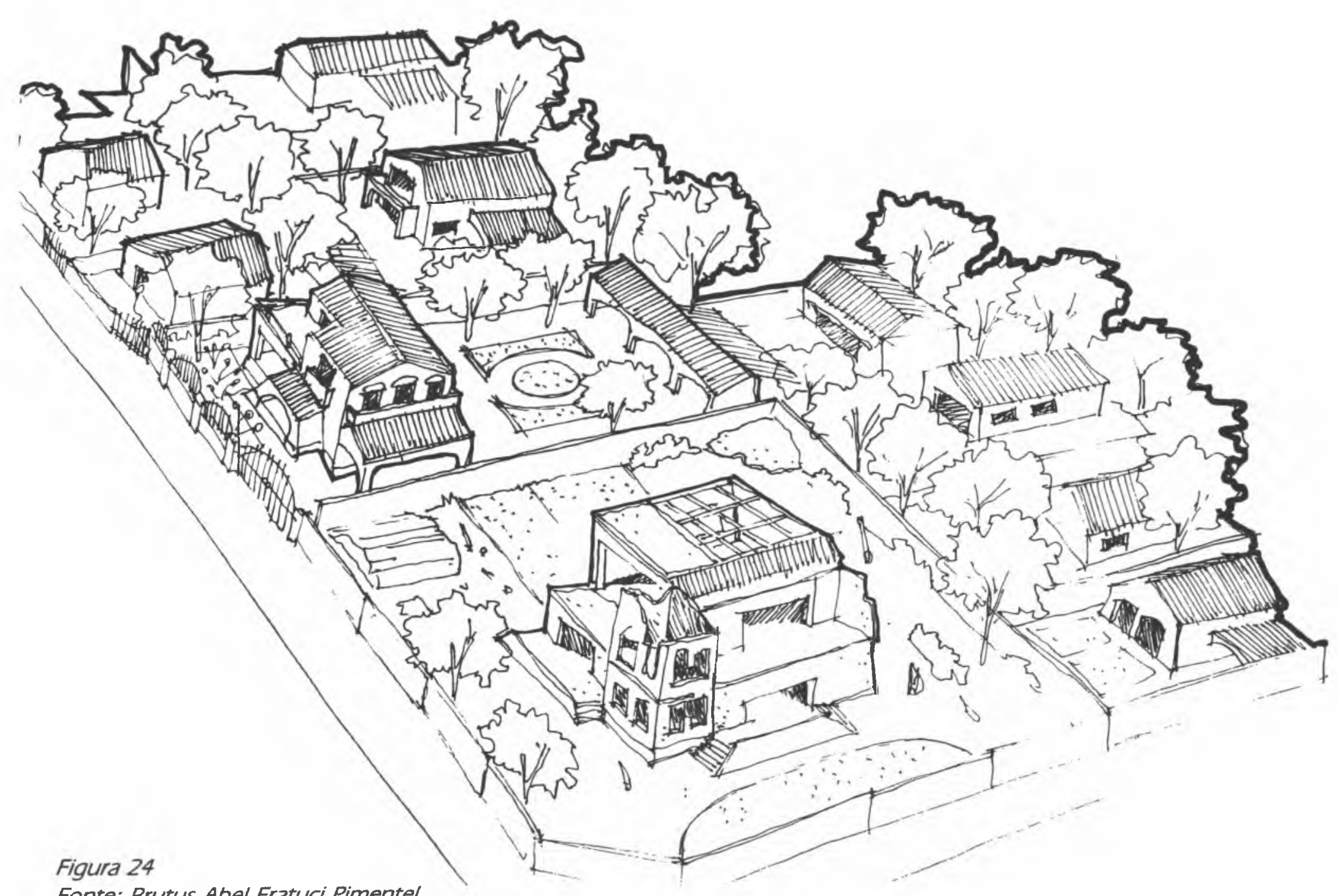

Fonte: Brutus Abel Fratuci Pimentel 
$\mathrm{Na}$ estrutura urbana da década de 50 (figura 25) figuram-se, portanto, duas vertentes: a casa tida como moderna, com garagens, muitas sem cerca na frente e com desenho paisagístico norte-americano, e a casa ainda com traços estilísticos adaptada para a vida moderna. Há uma mescla. Os espaços livres, portanto, não se definem ou se enquadram nos períodos e sim são levados ao sabor das exigências e das necessidades da família paulistana.

O padrão morfológico urbano paulistano, com relação às construções de moradia, representa um importante modificador da própria paisagem, o que podemos constatar atualmente através da incrivel diversidade tipológica das construções, bastante acentuada pelo

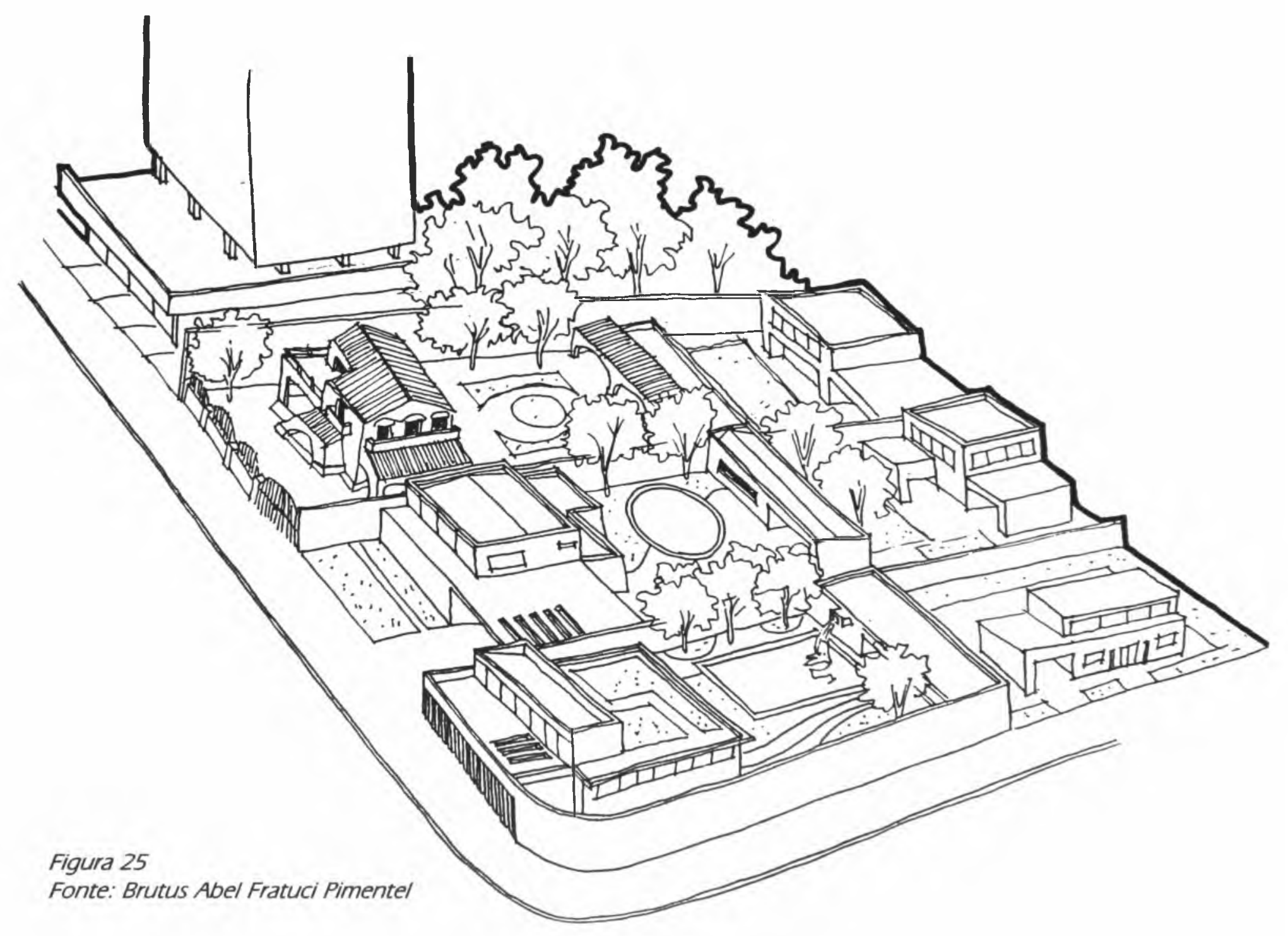


contraste de suas localizações onde co-habitam casas da década de 50 juntamente com edifícios modernos. Tal configuração demonstra a incrivel capacidade de transformação de uma cidade, que aceitou e fundiu diversas culturas em uma mesma malha urbana, tornando-a uma rica experiência visual para seus moradores.

Este texto é uma síntese baseada na pesquisa de iniciação científica desenvolvida na FAUUSP com o título de "As linhas projetuais da arquitetura paisagística no desenho dos espaços livres em São Paulo" Meus agradecimentos ao prof. Dr. Sílvio Soares Macedo pela sugestão e orientação do trabalho e ao apoio financeiro da Fapesp.

\section{BIBLIOGRA I A}

BARDI, P. M. The tropical gardens of Burle Maxx. Rio de Janeiro: Colibris, 1964.

BENEVOLO, Leonardo. História da arquitetura moderna. Sāo Paulo: Perspectiva S.A., 1989.

BLOSSFELD, Hary. Jardinagem. São Paulo: Melhoramentos.

BRUNO. Hernani da Silva. Histórias e tradições da cidade de São Paulo. São Paulo: José Olímpio. 1953. $3 \mathrm{v}$

CANABRAVA, Alice Piffer. As chácaras paulistanas: primeiros estudos. In: ASSOCIAÇÃO DOS GEÓGRAFOS BRASILEIROS. 1949-1950. São Paulo. Anais.

CARDOSO, Omar de Almeida. Quadro do paisagismo no Brasil. São Paulo, 1985. . A arquitetura paisagística e a cidade - do ecletismo ao moderno. Sāo Paulo, 1990.

Relatório final para o CNPq.

CASTILHA, Marcos da Silva. A arquitetura paisagística e a cidade - do ecletismo ao moderno. v. 1 e 2, São Paulo, 1990. Relatório apresentado ao CNPq.

DIERBERGER E CIA. Arte e jardim. Arquitetura e construção. São Paulo, 1929.

ECKBO, Garet. Landscape for living. Nova York: Dodge, 1950.

FABRIS, Annateresa (org.) Ecletismo na arquitetura brasileira. São Paulo: Nobel-Edusp, 1987.

GUARALDO, Elaine. Arquitetura paisagística - do ecletismo ao moderno. São Paulo: FAUUSP, 1990. Relatório apresentado ao CNPq

HOMEM, Maria Cecília Naclério. Higienópolis: grandeza e decadência de um bairro paulistano. São Paulo: Departamento do Patrimônio Histórico, 1980.

LEMOS, Carlos A C. A/venaria burguesa. São Paulo: Nobel, 1989. . Alvenaria brasileira. Sāo Paulo: Melhoramentos, 1979.

MACEDO, Sílvio Soares. Higienópolis e arredores: Processo de mutação da paisagem urbana. São Paulo: Edusp/Pini, 1987.

MOTTA, Flávio L. Burle Marx e a nova visão da paisagem. São Paulo: Nobel, 1983.

REID, Grant W. From concept to form landscape design. Nova York: Van Nostrand Reinhold, 1993.

REVISTA ACRÓPOLE (início da publicação: 1955) da Biblioteca da FAUUSP 
Brutus Os Espaços Livres Residenciais na

Abel

Cidade de São Paulo

Fratuci

Pimentel

REIS FILHO, Nestor Goulart. Quadro da arquitetura no Brasil. São Paulo: Perspectiva, 1987.

TOBEY, George B. History of landscape arquitecture - the relationship of people to environment. Nova York: Elsevier, 1973.

TOLEDO, Benedicto Lima. São Paulo: três cidades em um século. São Paulo: Livraria Duas Cidades, 1983.

ZANINI, Walter (org.). História geral da arte no Brasil. São Paulo: Instituto Walter Moreira Salles, 1983, v. I e II.

ZIMBER, Germano. Jardins de hoje. São Paulo: prefeitura, 1946.

\begin{tabular}{|c|c|c|}
\hline 40 & Paisagem & São Paulo n. 11 p. $13 \quad 40$ dez. 1998 \\
\hline & $\begin{array}{l}\text { Ensaios } \\
11\end{array}$ & \\
\hline
\end{tabular}

